\title{
Mass spectrometry of organic matter influenced by long-term pedogenesis and a short-term reclamation practice in an Oxisol of Brazil
}

\author{
Carlos M. Monreal, Marlene Cristina Alves, Morris Schnitzer, Sebastiao Nilce Souto Filho, and \\ Carolina dos Santos Batista Bonini
}

\begin{abstract}
Little is known about the influence of soil pedogenesis and reclamation practices on the chemical composition of soil organic matter (SOM) in eroded Oxisol. We examined the long-term influence of pedogenesis and 8 years of a reclamation practice on SOM in the top $5 \mathrm{~cm}$ of an artificially eroded Oxisol of Brazil. The experimental site involved replicated treatments established under native vegetation, and an adjacent site whose top $8.6 \mathrm{~m}$ had been removed mechanically (eroded reference). The eroded Oxisol was under reclamation with native tree and grass species, and addition of sewage sludge. Pyrolysis field ionization mass spectrometry was used to characterize SOM. The abundance of most classes of SOM and soil carbon decreased in the following order: native $>$ reclaimed >> eroded soil. Relative to the eroded reference, SOM in the native soil was highly humified and stabilized by inorganic colloids of iron, aluminum, and silicon. Humified and thermally stable SOM in the native and reference eroded soils involved mostly alkylaromatics, lipids, phenols+lignin monomers, lignin dimers, and N-heterocyclics. The reclaimed soil SOM was less humified and less stable than the native Oxisol, showing significant contributions of carbohydrates, amino acids, and sterols derived from sewage sludge and plant residues.
\end{abstract}

Key words: oxisol, soil organic matter, chemical classes, mass spectrometry, erosion, soil reclamation.

Résumé : On sait peu de choses concernant l'influence de la pédogenèse et des pratiques de restauration du sol sur la composition chimique de la matière organique dans les oxisols érodés. Les auteurs ont étudié les effets à long terme de la pédogenèse et de 8 années de restauration du sol sur la matière organique présente dans la couche supérieure de $5 \mathrm{~cm}$ d'un oxisol du Brésil érodé artificiellement. Le site expérimental a fait l'objet de traitements répétés sous la végétation indigène, tandis qu'on a retiré mécaniquement la couche supérieure de 8,6 $\mathrm{m}$ d'un site adjacent afin d'en faire un site témoin sur le plan de l'érosion. L'oxisol érodé avait subi des travaux de restauration sous forme de plantation d'espèces indigènes d'arbres et de graminées, après enrichissement avec des boues usées. Les chercheurs ont recouru à un spectromètre de masse à ionisation portatif avec pyrolyse pour caractériser la matière organique. L'abondance de la plupart des classes de matière organique et de carbone organique diminue dans l'ordre suivant : sol intact > sol restauré >> sol érodé. Lorsqu'on effectue une comparaison avec le témoin érodé, on constate que la matière organique du sol naturel est très humifiée et que des colloïdes du fer, de l'aluminium et du silicium la stabilisent. La matière organique humifiée et thermiquement stable du sol naturel et du sol érodé utilisé comme témoin renferme surtout des alkylaromatiques, des lipides, des phénols combinés à des monomères de la lignine, des dimères de la lignine et des N-hétérocycliques. Celle du sol restauré est moins humifiée et moins stable que celle de l'oxisol naturel, avec d'importants apports d'hydrates de carbone, d'acides aminés et de stérols ayant pour origine les boues usées et des résidus végétaux. [Traduit par la Rédaction].

Mots-clés : oxisol, matière organique du sol, classes chimiques, spectrométrie de masse, érosion, restauration du sol.

\section{Introduction}

Soil organic matter (SOM) is central to sustaining and enhancing the quality and productivity of cultivated land (Monreal et al. 1995). Organic matter (OM) influences water retention, soil fertility, and structural stability, and as such, SOM is often used as an indicator of soil

Received 11 March 2015. Accepted 25 September 2015.

C.M. Monreal and M. Schnitzer. Eastern Cereal and Oilseed Research Centre, Agriculture and Agri-Food Canada, Ottawa, Ontario, Canada.

M.C. Alves, S.N.S. Filho, and C.S. Batista Bonini. Departamento de Fitossanidade Engenharia Rural e Solos, Universidade Estadual Paulista, São Paulo, Brazil.

Corresponding author: Carlos M. Monreal (email: carlos.monreal@agr.gc.ca). 
quality and for the successful management of savannas (Feigl et al. 1995; Dexter 2004). Chemical components of SOM, such as lipids and polysaccharides, influence soil aggregate and structure stability; amino acids and $\mathrm{N}$-heterocyclics may be used as substrates for the biotic mineralization of soil organic nitrogen $(\mathrm{N})$. Compounds of SOM, such as alkaloids, fatty acids, alkylamides, and polyphenols in SOM, represent metabolites of chemical signalling networks reflecting specific ecological functions in crop rhizospheres (Monreal and Schnitzer 2013, 2015).

The change in land use from natural grasslands to cropped land greatly affects the structural stability and decreases OM content in Oxisols of Brazil (Zinn et al. 2005) and in Acrisols and Luvisols of Mexico and Mollisols of Canada (van Veen and Paul 1981; Monreal et al. 2005). Intense conversion of forest to agricultural land has been a frequent land use change in areas of Brazil and other countries (Fearnside 1993). In tropical areas, changes in land use shift the composition of vegetation, which in turn affects the amount and quality of SOM input and the diversity of soil macro- and microfauna and microbial communities (Lavelle and Pashanasi 1989; Johnson et al. 2003). In general, agroforestry enhances nutrient storage after land conversion as compared with sole cropping systems in semitropical and tropical regions (Isaac et al. 2005; Monreal et al. 2005). Determining the impact of human activities on SOM in the tropics is of interest owing to sustainability risks to food security associated with increased agricultural, deforestation, and urbanization activities (Hernández and López 2002), and these activities can be examined using simulation models (Wendling et al. 2014).

Building hydroelectric dams involves anthropogenic activities that remove native vegetation, soil profiles, and surficial geologic deposits and result in land flooding. These engineering activities may catalyze the beginning of ecosystem degradation. The loss of topsoil is central to landscape restoration. Although agricultural land use takes into account soil fertility in as much as it affects crop growth, topsoil is equally important for storing OM that supports biological diversity and activities essential for nutrient cycling and maintenance of soil health and natural conservation services. In general, anthropogenically eroded areas display low resilience such that they cannot return to their previous state or the return happens extremely slowly. When measures for recovery are not taken, soil degradation may continue for many years. Reclamation measures can focus on the landscape recovery and also on the maintenance of the productive potential of the affected zone (Taboada-Castro et al. 2009).

Little is known about the effects of man-made soil erosion and subsequent reclamation practices on the amounts and chemical quality of SOM in Oxisols of Brazil. The objective of this study was to determine the amount and chemical composition of SOM in an Oxisol under native vegetation and in an adjacent eroded Oxisol that has been under reclamation for 8 years with plants and sewage sludge addition. An Oxisol whose top $8.6 \mathrm{~m}$ was mechanically removed for building a nearby hydro dam was used as a reference soil treatment to study changes in SOM chemical composition by pyrolysis field ionization mass spectrometry (Py-FIMS).

\section{Materials and Methods}

Field research plots were established to test the hypothesis that pedogenesis and reclamation practices influence the amount and distribution of chemical structures of SOM in an Oxisol of Brazil.

\section{Field location and climate}

The experimental research plots were established on flat land at the Experimental Farm of the Faculty of Engineering, Campus de Ilha Solteira of the Universidade Estadual Paulista, São Paulo, Brazil, in February 2004. The site is located $327 \mathrm{~m}$ above sea level and at $51^{\circ} 22^{\prime} \mathrm{W}, 20^{\circ} 22^{\prime} \mathrm{S}$. The average annual rainfall is $1370 \mathrm{~mm}$, the air temperature is $23.5^{\circ} \mathrm{C}$ with a relative air humidity of $75 \%$.

\section{Soil and treatments}

In 2004, field plots $(12 \mathrm{~m} \times 8 \mathrm{~m})$ were established in a weathered Oxisol of sandy clay loam to sandy loam texture (EMBRAPA 2013). The field experiment was set as a completely randomized block, with three soil treatments; each treatment was replicated four times. Treatment 1 involved mechanically induced soil erosion of a native Savanna soil, where the top $8.6 \mathrm{~m}$ (including the A horizon and part of the B horizon) of soil was removed. Treatment 1 , which had no plant cover, was used as a reference eroded benchmark soil to study the amount and chemical changes of OM in the other two treatments. Treatment 2 (native Oxisol) involved an undisturbed Oxisol site under various plant species described in the subsequent section. Treatment 3 (reclaimed Oxisol) involved the mechanically eroded soil planted with tree and grass species together with addition of sewage sludge and lime. The research plots for Treatments 1 and 3 that were established in the eroded Oxisol on saprolite, have a less weathered regolith than the original native Oxisol (Kitamura et al. 2008; Taboada-Castro et al. 2009).

\section{Vegetation and reclamation practice}

Under soil Treatment 2, the native Oxisol had a permanent cover of mixed trees, including Curatella americana, Stryphnodendron adstringens, Byrsonima verbascifolia, and Astronium faxinifolium Schott. The last tree species are hardwood perennial species native to Brazil, belonging to the family Anacardiaceae. The soil plots undergoing the reclamation practice (Treatment 3 ) were planted with trees and grasses in year 1 of the study. The tree species was Astronium fraxinifolium Schott planted in a spacing of $3 \mathrm{~m} \times 2 \mathrm{~m}$ to give a density of 25 trees $\mathrm{plot}^{-1}$. The 
Fig. 1. Py-FIMS spectra for soil organic matter found in the $0-5 \mathrm{~cm}$ depth of the (A) native Oxisol, (B) reclaimed Oxisol, and (C) reference eroded Oxisol.
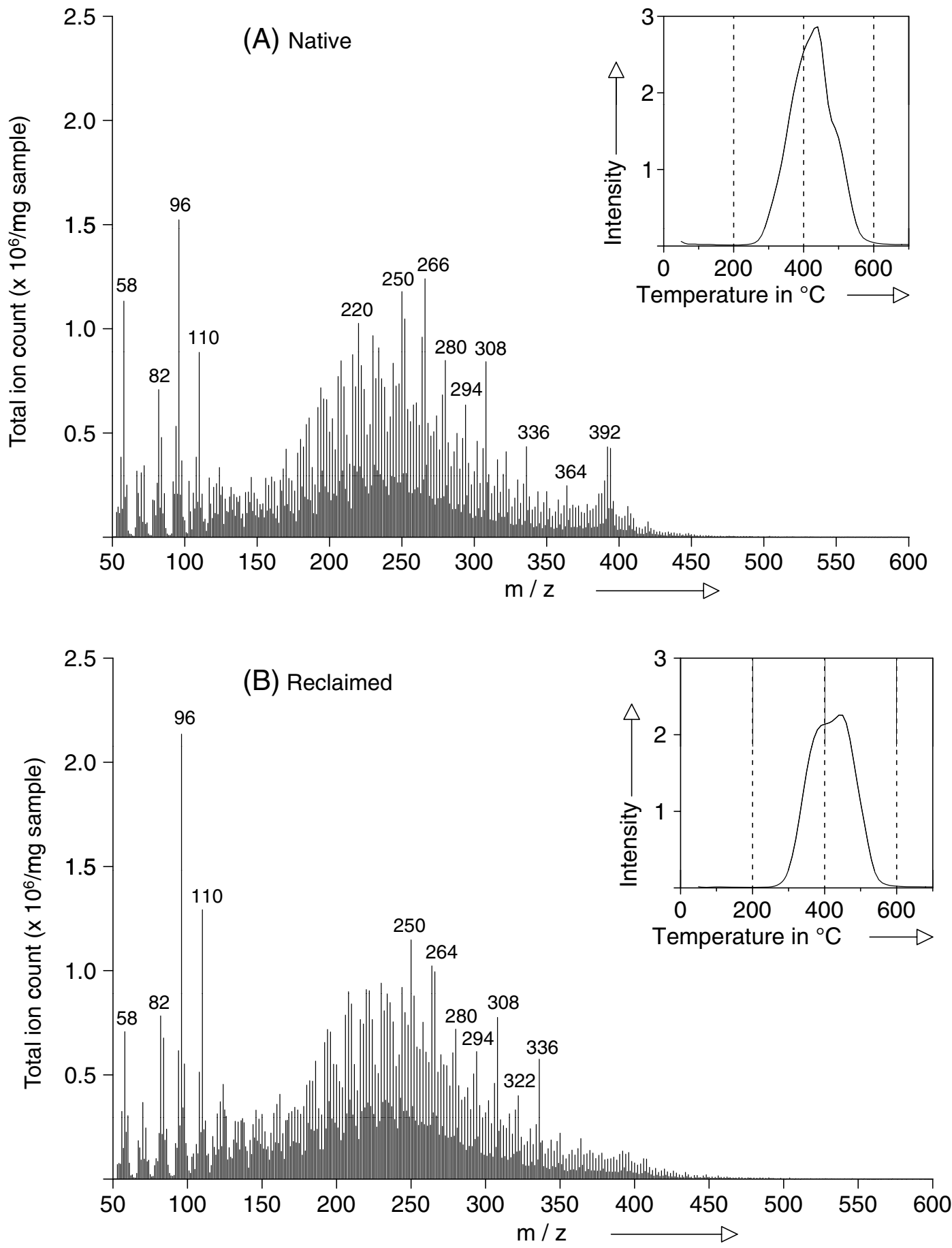

grass Urochloa decumbens Stapf was seeded at a rate of $16 \mathrm{~kg} \mathrm{ha}^{-1}$ between the tree rows ( $3 \mathrm{~m}$ apart). The soil reclamation treatment also received a one-time addition of municipal sewage sludge (60 t ha ${ }^{-1}$, dry basis) and a one-time addition of dolomite lime (CaO: $28-31 \% \mathrm{w} / \mathrm{w}$; MgO: 18-21\% $w / w)$ applied at $2 \mathrm{t} \mathrm{ha}^{-1}$ in February 2004. The sewage sludge and lime were incorporated and mixed into the soil with a plow to $20 \mathrm{~cm}$ depth, then harrowed and levelled. There was no vegetation growing in the reference eroded soil Treatment 1 . Further details on other tillage equipment and operations, spatial distribution of plots, and some chemical and physical properties of the studied soils have been published earlier by Alves and Suzuki (2007).

Soil sampling, sample processing and analysis

In 2012, soil samples were taken with a handheld core sampler (8 cm diameter) from the $0-5 \mathrm{~cm}$ soil depth, at 
Fig. 1 (concluded).

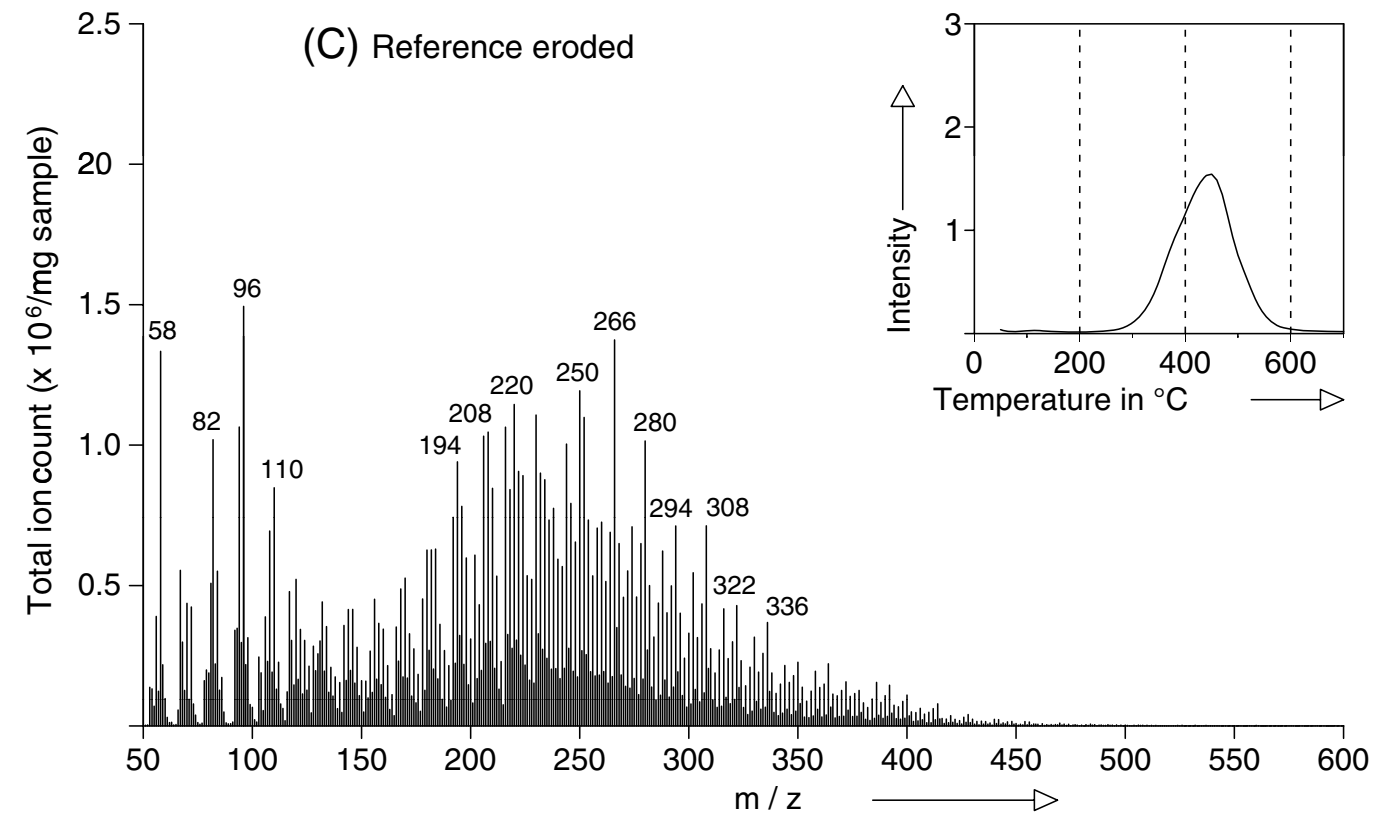

Table 1. The content of inorganic and organic components in the $0-5 \mathrm{~cm}$ depth of a native and reclaimed relative to a reference eroded Oxisol.

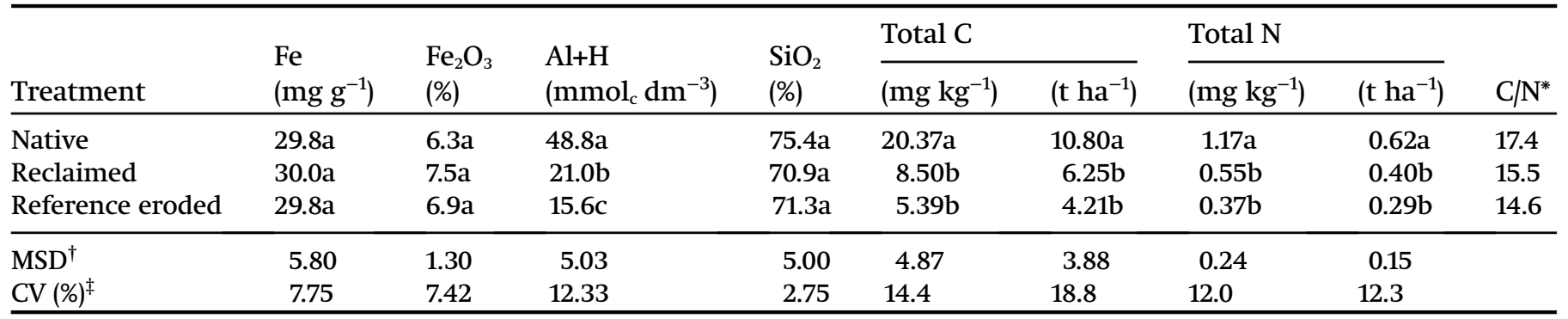

Note: Within each column, values not followed by the same letter are significantly different at the $5 \%$ level (Tukey test).

${ }^{*} \mathrm{C} / \mathrm{N}$ value rounded up to the next digit.

${ }^{\dagger}$ MSD, minimum significant difference $(p<0.05)$.

${ }^{\ddagger} \mathrm{CV}$, coefficient of variation.

five randomly selected locations inside each replicated treatment plot. For example, soil samples from the surface $0-5 \mathrm{~cm}$ depth were collected from the A horizon in the native site, and from the $0-5 \mathrm{~cm}$ depth of the saprolite soil substrate in the reclaimed and reference eroded Oxisols. The five samples taken randomly from each replicated plot were pooled together into a composite sample and mixed thoroughly to produce a representative soil sample. Collected soil samples were oven-dried at $105{ }^{\circ} \mathrm{C}$ and ground to pass through a 100-mesh sieve before physical and chemical analysis.

Soil particle size analysis followed the pipette method (EMBRAPA 1997). Total iron (Fe), $\mathrm{Fe}_{2} \mathrm{O}_{3}$, and $\mathrm{SiO}_{2}$ were analyzed by X-ray fluorescence spectrometry, and mineral components were microwave extracted with nitric acid and subsequently analyzed by inductively coupled plasma mass spectrometry (UH 2011). The content of
$\mathrm{Al}+\mathrm{H}$ species (potential acidity) was determined by soil extraction with calcium chloride $\left(0.01 \mathrm{~mol} \mathrm{~L}^{-1}\right)$ buffered with the Shoemaker, McLean, and Pratt solution at pH 7.5 (van Raij et al. 2001). The $\mathrm{Al}+\mathrm{H}$ represents the aluminum (Al) species in the soil solution and easily exchangeable pools determined by titration. Other chemical and morphological properties of the soil and chemical composition of the sewage sludge have been reported by Paz-Ferreiro and Alves (2012) and Bonini et al. (2015).

The concentration $(\% w / w)$ of carbon $(\mathrm{C})$ and $\mathrm{N}$ were determined by dry combustion at the stable isotope laboratory of the University of Ottawa. The soil samples were weighed into tin capsules and flash combusted with oxygen at $1800{ }^{\circ} \mathrm{C}$ and carried by helium through columns of reducing-oxidizing chemicals to get $\mathrm{N}_{2}$ and $\mathrm{CO}_{2}$. The gases were separated by "trap and purge" 
Fig. 2. Thermograms of selected classes for organic compounds volatilized from the (A) native Oxisol, (B) reclaimed Oxisol, and (C) reference eroded Oxisol.

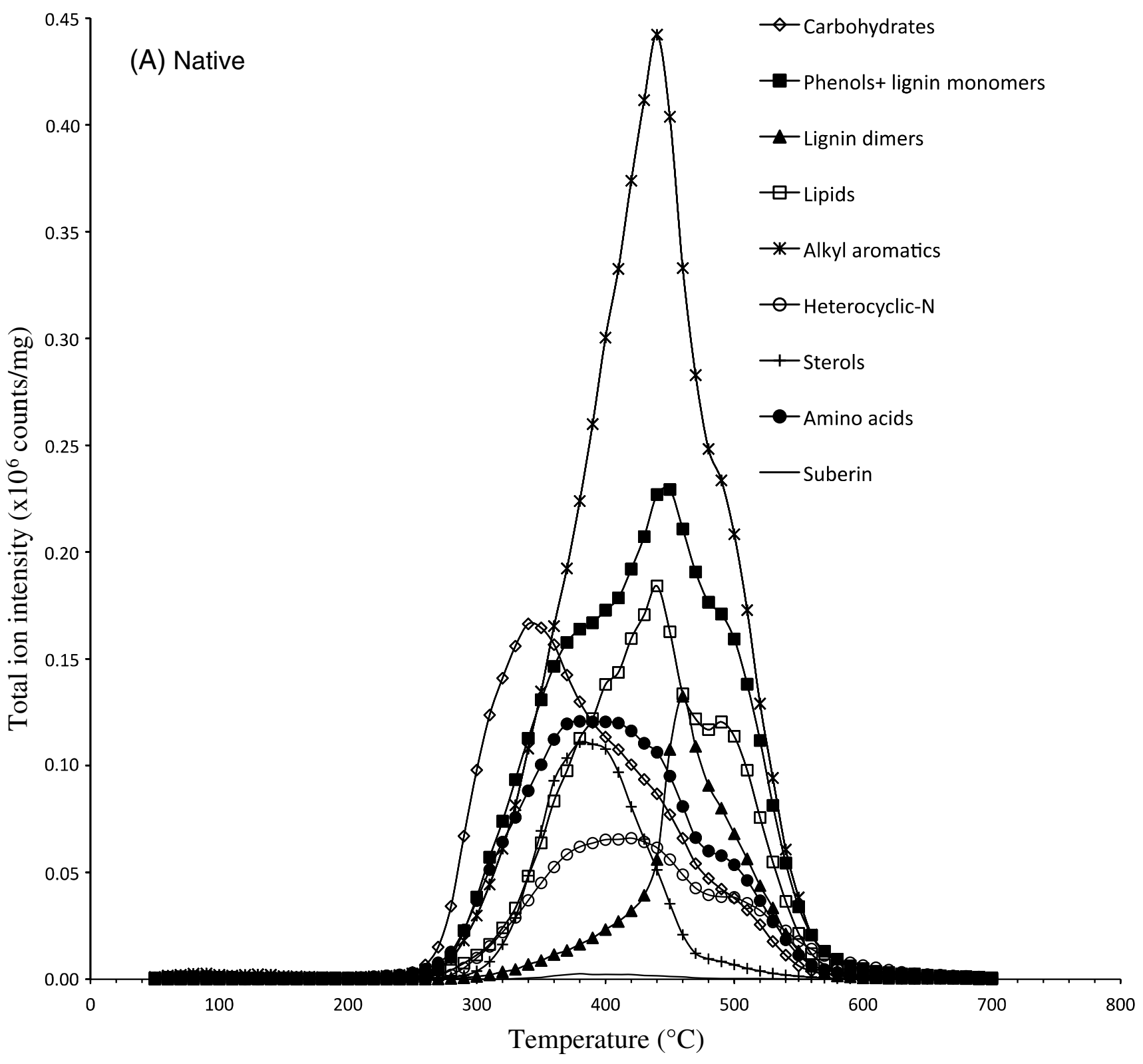

of specific adsorption columns so that the thermal conductivity detector could detect each gas separately. The analytical precision is $\pm 0.1 \%$ (http://www.isotope. uottawa.ca/techniques/quantitative-analysis.html\#vario).

\section{Py-FIMS}

The SOM composition in samples collected from the $0-5 \mathrm{~cm}$ depth in the native, reclaimed, and reference eroded soil samples was investigated by Py-FIMS. PyFIMS is a soft-ionization mass spectrometric method, which means there is little fragmentation, so that most signals volatized during pyrolysis from the soil sample are molecular ions. Briefly, $1 \mathrm{mg}$ of sample was air-dried in a sample tube and then heated in the direct inlet system of a double-focusing mass spectrometer
(Finnigan MAT 731, Bremen) under high vacuum $\left(1 \times 10^{-4} \mathrm{~Pa}\right)$ from 50 to $700{ }^{\circ} \mathrm{C}$ at a programmed linear heating rate of $10{ }^{\circ} \mathrm{C} \mathrm{min}{ }^{-1}$. Sixty mass spectra were recorded over the mass range $m / z$ 15-900 Da. The signals in all spectra were integrated and plotted to yield a summed spectrum (Sorge et al. 1993). For example, Figs, $1 \mathrm{~A}-1 \mathrm{C}$ show that the total ion intensities (TII), normalized to $1 \mathrm{mg}$ sample mass, were plotted against pyrolysis temperatures to yield thermograms (Schnitzer and Monreal 2011).

\section{Identification of mass spectrometric signals}

The ion intensity of each mass spectrometric signal was computed from the mass spectra. The sum of all IIs was referred to as TIIs. The II of each signal identified 
Fig. 2 (continued).

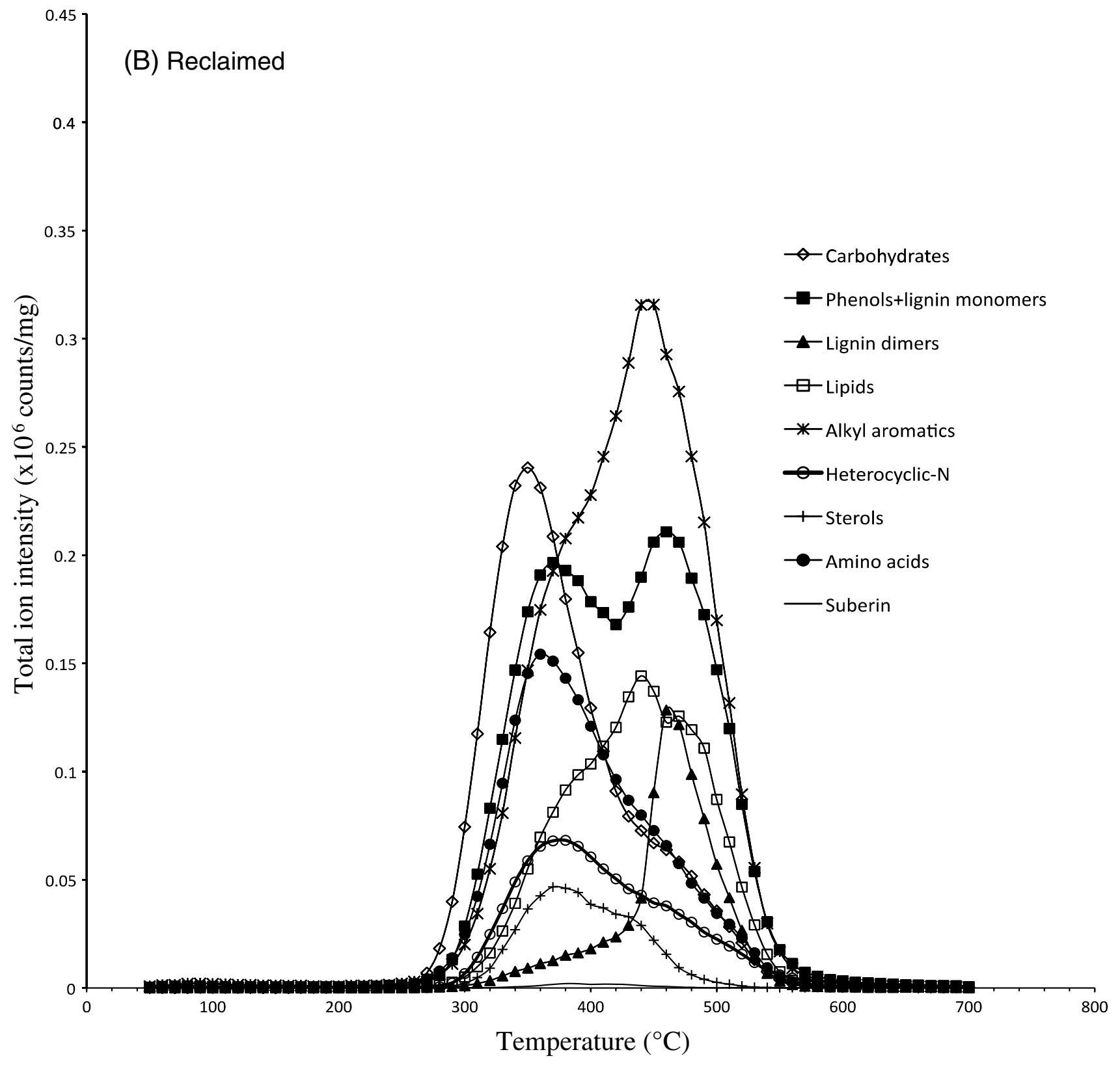

was a semiquantitative estimate of its concentration. Identifications of the major signals in the Py-FIMS spectra were based on comparisons with data published in the literature and, when available, on compounds with known chemical structures.

\section{Analysis of sugars and polysaccharides}

The mass spectrometric method which we used for sugars has been previously reported by Schulten (1984) and Kögel et al. (1988). The following mass signals were used for hexoses: $m / z 126,144$, and 162; for pentoses: $m / z 114$ and 132; and for polysacchrides: $m / z$ 60, 72, 82, $84,96,98,110$, and 112 . Hexoses include glucose, galactose, and mannose, while pentoses refer to arabinose and xylose.
Identification of the remaining $\mathrm{m} / \mathrm{z}$ signals

The identification of the $\mathrm{m} / z$ signals due to other chemical classes of compounds was described previously by Hempfling and Schulten (1990), Schnitzer and Schulten (1992), Sorge et al. (1993), Schnitzer and Monreal (2011), Monreal and Schnitzer (2013). Additional $\mathrm{m} / z$ values were identified with the help of the NIST chemical webbook (http://webbook.nist.gov) of the National Institute of Standards and Technology of the USA.

\section{Statistical analyses}

Analysis of variance (ANOVA) was conducted to determine significant differences in the content of soil inorganic and organic elements in the three Oxisol 
Fig. 2 (concluded).

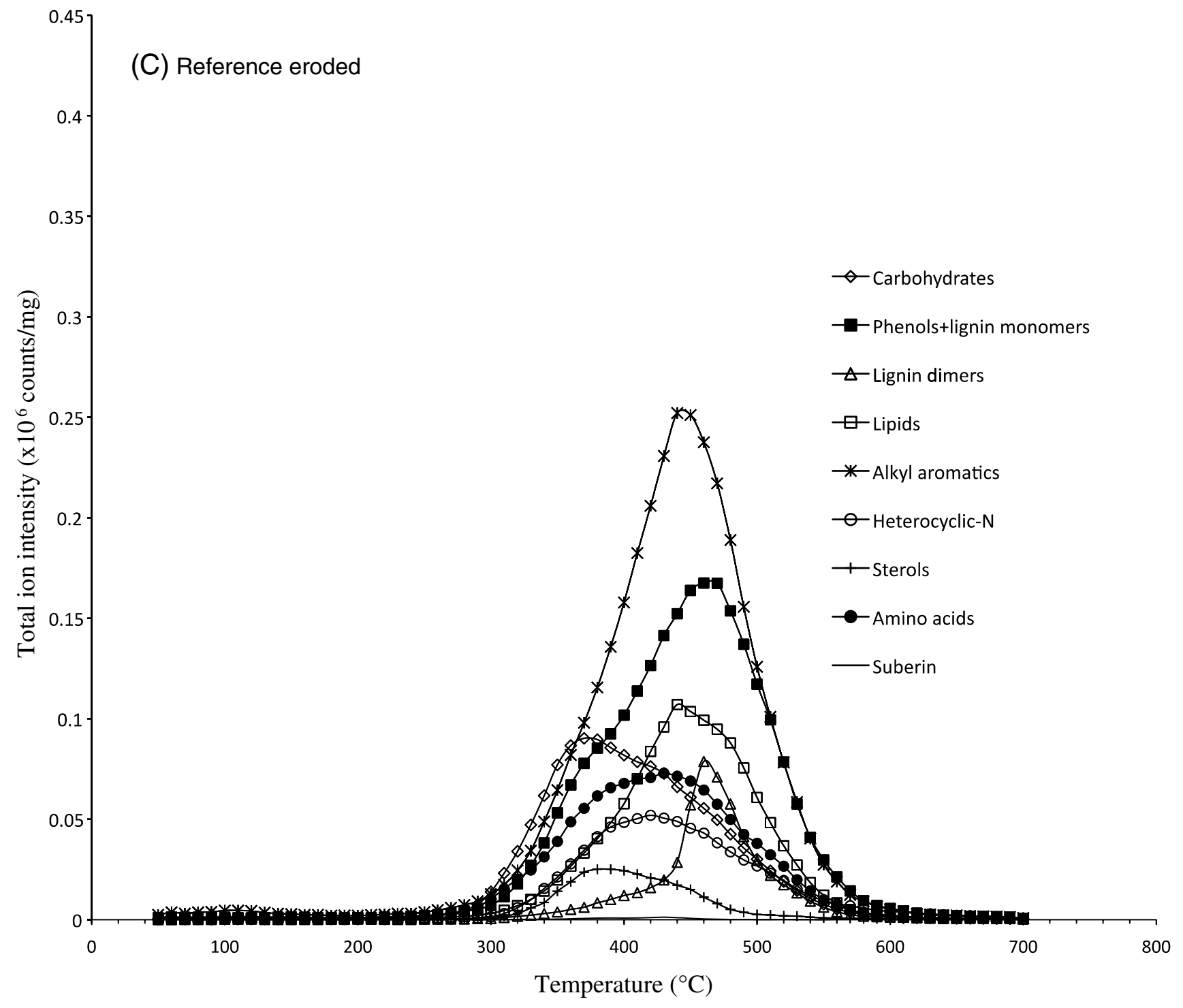

established treatments (Ferreira 2008). Paired $t$ tests were run to determine the significance level of differences of the mean values for each of the chemical classes of compounds observed between the native, reclaimed, and eroded soil management treatments.

\section{Results}

\section{Soil texture}

The native and reclaimed soils were sandy clay loam and the reference eroded soil was sandy loam. The content of clay in the native soil was $281 \mathrm{~g} \mathrm{~kg}^{-1}$, in the reclaimed soil it was $289 \mathrm{~g} \mathrm{~kg}^{-1}$, and $163 \mathrm{~g} \mathrm{~kg}^{-1}$ in the reference eroded samples. The content of sand was $597 \mathrm{~g} \mathrm{~kg}^{-1}$ in the native, $642 \mathrm{~g} \mathrm{~kg}^{-1}$ in the reclaimed soil, and $775 \mathrm{~g} \mathrm{~kg}^{-1}$ in the reference eroded samples. The content of silt was $122 \mathrm{~g} \mathrm{~kg}^{-1}$ in the native, $69 \mathrm{~g} \mathrm{~kg}^{-1}$ in the reclaimed, and $62 \mathrm{~g} \mathrm{~kg}^{-1}$ in the reference eroded soil samples.
Inorganic soil components

Table 1 shows the content of $\mathrm{Fe}, \mathrm{Fe}_{2} \mathrm{O}_{3}, \mathrm{SiO}_{2}$, and the $\mathrm{Al}+\mathrm{H}$ species in the soil samples collected from the 0-5 cm depth of the three treatments. With the exception of $\mathrm{Al}+\mathrm{H}$ species, the content of the inorganic elements and their mineral structures in soil samples were similar between the three soil treatments. The content of $\mathrm{Al}+\mathrm{H}$ decreased in the following order: native $>$ reclaimed $>$ eroded.

\section{Carbon and $N$ content in soil and sewage sludge}

The total content of $\mathrm{C}$ and $\mathrm{N}\left(\% w / w, \mathrm{t} \mathrm{ha}^{-1}\right)$ in the top $5 \mathrm{~cm}$ of the three Oxisol treatments is shown in Table 1. The samples from the native site showed significantly higher content of both elements than the reclaimed and reference eroded soil samples. According to Tukey's test, the amounts of $\mathrm{C}$ and $\mathrm{N}$ in the reclaimed and reference eroded soil were similar, although their 
Table 2. Ion intensities for $m / z$ assigned to carbohydrates in samples obtained from the $0-5 \mathrm{~cm}$ depth of native and reclaimed phases relative to a reference eroded Oxisol.

\begin{tabular}{|c|c|c|c|}
\hline \multirow[b]{2}{*}{$m / z$} & \multicolumn{3}{|c|}{ Ion intensity (counts $\mathrm{mg}^{-1}$ ) } \\
\hline & Native & Reclaimed & $\begin{array}{l}\text { Reference } \\
\text { eroded }\end{array}$ \\
\hline & \multicolumn{3}{|c|}{ Hexoses } \\
\hline 126 & 52798 & 56214 & 23709 \\
\hline 144 & 94943 & 97576 & 92222 \\
\hline 162 & 116709 & 151607 & 47917 \\
\hline \multirow[t]{2}{*}{ Subtotal } & 264449 & 305397 & 163848 \\
\hline & \multicolumn{3}{|c|}{ Pentoses } \\
\hline 114 & 37821 & 44978 & 13814 \\
\hline 132 & 90088 & 96573 & 63013 \\
\hline \multirow[t]{2}{*}{ Subtotal } & 90088 & 96573 & 63013 \\
\hline & \multicolumn{3}{|c|}{ Polysaccharides } \\
\hline 60 & 54801 & 56672 & 10828 \\
\hline 72 & 75037 & 45704 & 47191 \\
\hline 82 & 154835 & 145830 & 113551 \\
\hline 84 & 104600 & 125993 & 61341 \\
\hline 96 & 332987 & 397660 & 166354 \\
\hline 98 & 80093 & 102934 & 35030 \\
\hline 110 & 193787 & 240731 & 94484 \\
\hline 112 & 90614 & 104080 & 50541 \\
\hline Subtotal & 1086752 & 1219502 & 579319 \\
\hline Total* & 1441288 & 1621471 & 806179 \\
\hline
\end{tabular}

content tended to be higher in the reclaimed than in the eroded soil after 8 years of soil reclamation. The $\mathrm{C} / \mathrm{N}$ ratio of SOM was near 15 in the reference eroded and reclaimed

samples, and 17 in the native soil samples, indicating a relatively higher degree of $\mathrm{C}$ decomposition and humification of OM in the native than in the other two Oxisol treatments. The concentration of $\mathrm{C}$ and $\mathrm{N}$ in the added sewage sludge was 206 and $71.3 \mathrm{~g} \mathrm{~kg}^{-1}$ soil (dry basis), respectively. The annual production of Urochloa decumbens dry matter in the reclaimed soil was $25672 \mathrm{~kg} \mathrm{ha}^{-1}$. Although the annual production of dry plant matter was not measured in the native Oxisol, the range in production for aboveground biomass in a Cerrado biome with predominance of clayey Oxisol is similar to that measured in the reclaimed treatment (Lannes et al. 2012).

\section{Thermal stability of SOM during sample pyrolysis}

The thermal volatilization pattern of the total SOM in the native, reclaimed, and reference eroded Oxisol
Table 3. Ion intensities for $m / z$ assigned to amino acids in samples obtained from the $0-5 \mathrm{~cm}$ depth of native and reclaimed phases relative to a reference eroded Oxisol.

\begin{tabular}{|c|c|c|c|}
\hline \multirow[b]{2}{*}{$m / z$} & \multicolumn{3}{|c|}{ Ion intensity (counts $\mathrm{mg}^{-1}$ ) } \\
\hline & Native & Reclaimed & $\begin{array}{l}\text { Reference } \\
\text { eroded }\end{array}$ \\
\hline & \multicolumn{3}{|c|}{ Acidic amino acids } \\
\hline 70 & 135044 & 136972 & 97249 \\
\hline 84 & 104600 & 125993 & 61341 \\
\hline 97 & 88728 & 127601 & 48701 \\
\hline 99 & 42113 & 63707 & 17072 \\
\hline 115 & 12472 & 11452 & 4042 \\
\hline \multirow[t]{2}{*}{ Subtotal } & 382957 & 465725 & 228405 \\
\hline & \multicolumn{3}{|c|}{ Neutral amino acids } \\
\hline 57 & 29551 & 27503 & 13767 \\
\hline 73 & 27043 & 30954 & 17395 \\
\hline 75 & 7132 & 8197 & 2654 \\
\hline 87 & 9289 & 12475 & 5517 \\
\hline \multirow[t]{2}{*}{ Subtotal } & 73015 & 79129 & 39333 \\
\hline & \multicolumn{3}{|c|}{ Neutral aromatic amino acids } \\
\hline 74 & 15106 & 16789 & 4296 \\
\hline 91 & 3662 & 3309 & 1567 \\
\hline 120 & 52331 & 58320 & 58088 \\
\hline 135 & 44592 & 52402 & 26795 \\
\hline \multirow[t]{2}{*}{ Subtotal } & 115690 & 130819 & 90746 \\
\hline & \multicolumn{3}{|c|}{ Basic amino acids } \\
\hline 129 & 27128 & 19598 & 21903 \\
\hline 135 & 44592 & 52402 & 26795 \\
\hline Subtotal & 71720 & 72000 & 48698 \\
\hline Total $^{*}$ & 643381 & 747673 & 407780 \\
\hline
\end{tabular}

${ }^{*} t$ test (total): native vs reclaimed $p=0.020$; native vs reference eroded $p=0.0005$; reclaimed vs reference eroded $p=0.0015$.

during sample pyrolysis is shown in the upper right corner of Figs. 1A-1C. The pyrolysis of the native Oxisol produced the highest intensity maximum exothermic volatilization peak near $450{ }^{\circ} \mathrm{C}$ with a slight shoulder near $\sim 500{ }^{\circ} \mathrm{C}$ (Fig. 1A). In comparison, the pyrolysis of the reclaimed soil samples produced an intermediate intensity exothermic volatilization peak near 380$390{ }^{\circ} \mathrm{C}$, and a second maximum exothermic peak occurred near $450-460{ }^{\circ} \mathrm{C}$ (Fig. 1B). In the reference eroded samples, the single maximum exothermic volatilization peak of relatively lower intensity occurred near $460{ }^{\circ} \mathrm{C}$ (Fig. 1C). In this article, we defined thermolabile SOM as being represented by maximum peaks that volatilized at $<440{ }^{\circ} \mathrm{C}$ and thermostable SOM by maximum peaks that volatilized at $>450{ }^{\circ} \mathrm{C}$ (Monreal et al. 1997). 
Table 4. Chemical structures for $m / z$ assigned to phenols and lignin monomers in samples obtained from the $0-5 \mathrm{~cm}$ depth of native and reclaimed phases relative to a reference eroded Oxisol.

\begin{tabular}{|c|c|c|c|c|c|c|c|}
\hline$m / z$ & Structure & $R_{1}$ & $R_{2}$ & $R_{3}$ & $R_{4}$ & $R_{5}$ & $R_{6}$ \\
\hline 94 & & $-\mathrm{OH}$ & $-\mathrm{H}$ & $-\mathrm{H}$ & $-\mathrm{H}$ & $-\mathrm{H}$ & $-\mathrm{H}$ \\
\hline 108 & & $-\mathrm{OH}$ & $-\mathrm{CH}_{3}$ & $-\mathrm{H}$ & $-\mathrm{H}$ & $-\mathrm{H}$ & $-\mathrm{H}$ \\
\hline 110 & & $-\mathrm{OH}$ & $-\mathrm{OH}$ & $-\mathrm{H}$ & $-\mathrm{H}$ & $-\mathrm{H}$ & $-\mathrm{H}$ \\
\hline 122 & & $-\mathrm{OH}$ & $-\mathrm{CH}_{3}$ & $-\mathrm{CH}_{3}$ & $-\mathrm{H}$ & $-\mathrm{H}$ & $-\mathrm{H}$ \\
\hline 124 & & $-\mathrm{H}$ & $-\mathrm{H}$ & $-\mathrm{OCH}_{3}$ & $-\mathrm{OH}$ & $-\mathrm{H}$ & $-\mathrm{H}$ \\
\hline 126 & & $-\mathrm{H}$ & $-\mathrm{H}$ & $-\mathrm{OH}$ & $-\mathrm{OH}$ & $-\mathrm{OH}$ & $-\mathrm{H}$ \\
\hline 138 & & $-\mathrm{CH}_{3}$ & $-\mathrm{H}$ & $-\mathrm{OCH}_{3}$ & $-\mathrm{OH}$ & $-\mathrm{H}$ & $-\mathrm{H}$ \\
\hline 140 & & $-\mathrm{OH}$ & $-\mathrm{H}$ & $-\mathrm{OCH}_{3}$ & $-\mathrm{OH}$ & $-\mathrm{H}$ & $-\mathrm{H}$ \\
\hline 150 & & $-\mathrm{CH}=\mathrm{CH}_{2}$ & $-\mathrm{H}$ & $-\mathrm{OCH}_{3}$ & $-\mathrm{OH}$ & $-\mathrm{H}$ & $-\mathrm{H}$ \\
\hline 152 & & $-\mathrm{CHO}$ & $-\mathrm{H}$ & $-\mathrm{OCH}_{3}$ & $-\mathrm{OH}$ & $-\mathrm{H}$ & $-\mathrm{H}$ \\
\hline 154 & & $-\mathrm{H}$ & $-\mathrm{H}$ & $-\mathrm{OCH}_{3}$ & $-\mathrm{OH}$ & $-\mathrm{OCH}_{3}$ & $-\mathrm{H}$ \\
\hline 164 & & $-\mathrm{CH}_{2}-\mathrm{CH}=\mathrm{CH}_{2}$ & $-\mathrm{H}$ & $-\mathrm{OCH}_{3}$ & $-\mathrm{OH}$ & $-\mathrm{H}$ & $-\mathrm{H}$ \\
\hline 166 & $\mathrm{R}_{4}$ & $-\mathrm{CH}_{2}-\mathrm{CH}_{2}-\mathrm{CH}_{3}$ & $-\mathrm{H}$ & $-\mathrm{OCH}_{3}$ & $-\mathrm{OH}$ & $-\mathrm{H}$ & $-\mathrm{H}$ \\
\hline 168 & & $-\mathrm{COOH}$ & $-\mathrm{H}$ & $-\mathrm{OCH}_{3}$ & $-\mathrm{OH}$ & $-\mathrm{H}$ & $-\mathrm{H}$ \\
\hline 178 & & $-\mathrm{CH}=\mathrm{CH}=\mathrm{CHO}$ & $-\mathrm{H}$ & $-\mathrm{OCH}_{3}$ & $-\mathrm{OH}$ & $-\mathrm{H}$ & $-\mathrm{H}$ \\
\hline 180 & & $-\mathrm{CH}=\mathrm{CH}-\mathrm{CH}_{2} \mathrm{OH}$ & $-\mathrm{H}$ & $-\mathrm{OCH}_{3}$ & $-\mathrm{OH}$ & $-\mathrm{H}$ & $-\mathrm{H}$ \\
\hline 182 & & $-\mathrm{CHO}$ & $-\mathrm{H}$ & $-\mathrm{OCH}_{3}$ & $-\mathrm{OH}$ & $-\mathrm{OCH}_{3}$ & $-\mathrm{H}$ \\
\hline 194 & & $-\mathrm{CH}=\mathrm{CH}=\mathrm{COOH}$ & $-\mathrm{H}$ & $-\mathrm{OCH}_{3}$ & $-\mathrm{OH}$ & $-\mathrm{OCH}_{3}$ & $-\mathrm{H}$ \\
\hline 196 & & $-\mathrm{CH}_{2}-\mathrm{CHO}$ & $-\mathrm{H}$ & $-\mathrm{OCH}_{3}$ & $-\mathrm{OH}$ & $-\mathrm{OCH}_{3}$ & $-\mathrm{H}$ \\
\hline 208 & & $-\mathrm{CH}=\mathrm{CH}-\mathrm{CHO}$ & $-\mathrm{H}$ & $-\mathrm{OCH}_{3}$ & $-\mathrm{OH}$ & $-\mathrm{OCH}_{3}$ & $-\mathrm{H}$ \\
\hline 210 & & $-\mathrm{CH}=\mathrm{CH}-\mathrm{CH}_{2} \mathrm{OH}$ & $-\mathrm{H}$ & $-\mathrm{OCH}_{3}$ & $-\mathrm{OH}$ & $-\mathrm{OCH}_{3}$ & $-\mathrm{H}$ \\
\hline 212 & & $-\mathrm{CH}_{2}-\mathrm{COOH}$ & $-\mathrm{H}$ & $-\mathrm{OCH}_{3}$ & $-\mathrm{OH}$ & $-\mathrm{OCH}_{3}$ & $-\mathrm{H}$ \\
\hline
\end{tabular}

The Py-FIMS analysis shows that the thermolabile and thermostable pools of SOM comprised different chemical classes of compounds (Tables 2-16). In all three Oxisol phases, the chemical classes contributing to the thermostable $\mathrm{OM}$ pool at $>450{ }^{\circ} \mathrm{C}$ are mostly alkylaromatics, lipids, phenols+lignin monomers, lignin dimers, and $\mathrm{N}$-heterocyclics (Figs. 2A-2C). In addition, lipids and $\mathrm{N}$-heterocyclics showed a second thermostable shoulder component at $>500{ }^{\circ} \mathrm{C}$, especially in the native soil (Fig. 2A). Molecular examples of the thermostable SOM involved various derivatives of alkylbenzene, saturated and unsaturated fatty acids and alkanes, various phenols and lignin monomers, biphenyls, and phenylcoumarans (Tables 4, 7, 8, and 11).

Chemical classes of compounds contributing to the volatilization of the thermolabile pools of SOM involved carbohydrates with an exothermal maximum peak near $320^{\circ} \mathrm{C}$, and contributions of amino acids and sterols were observed from 390 to $400{ }^{\circ} \mathrm{C}$ (Figs. 2A-2C).

\section{Mass spectrometry of SOM}

The Py-FIMS spectra of the native, reclaimed, and eroded soils are shown in Figs. 1A-1C, respectively. Each of the three spectra extends from $m / z 10$ to $m / z 500$, where $m / z$ signals are well separated from each other. Noteworthy, the volatilized OM from the three soil samples appear to be free of relatively high molecular weight compounds (i.e., alkyl esters), which would be expected in the 600-900 $\mathrm{m} / \mathrm{z}$ region.

We identified 12 chemical classes of compounds in each of the three soil treatments. These are listed in Tables 2-16 along with the ion intensities (IIs) for each organic compound identified in each class. The IIs stand for abundance of the organic molecular ions that were volatilized during pyrolysis. The chemical classes identified were carbohydrates, amino acids, phenols+lignin monomers, lignin dimers, alkyl aromatics (alkylbenzenes), flavonoids, $n$-alkanes $+n$-fatty acids (lipids), $n$-diols, $\mathrm{N}$-heterocyclics, nitriles, sterols+steroids, and esters of suberins. The alkyl radicals are not considered a class by themselves, as they are formed during pyrolysis of long-chain aliphatics existing in SOM. In terms of the total chemical classes recovered from each Oxisol treatment, the Py-FIMS analysis of samples reported $32.8 \times 10^{6}$ counts $\mathrm{mg}^{-1}$ in the native samples, $29.4 \times 10^{6}$ counts $\mathrm{mg}^{-1}$ in the reclaimed samples, and $18.2 \times 10^{6}$ counts $\mathrm{mg}^{-1}$ in the reference eroded samples. In terms of the total chemical classes identified, these values correspond to $75 \%$ for the native soil, $67 \%$ for the reclaimed soil, and $42 \%$ for the reference eroded soil (Table 16). Overall, the abundance of chemical classes of compounds in all three Oxisol treatments decreased in the following order: lipids $>N$-heterocyclics $>>n$ alkylbenzenes $>$ phenols+lignin monomers $>n$-diols $>$ lignin dimers $>$ carbohydrates $>$ flavonoids $>$ amino 
Table 5. Ion intensities for $m / z$ assigned to phenols and lignin monomers in samples obtained from the $0-5 \mathrm{~cm}$ depth of native and reclaimed phases relative to a reference eroded Oxisol.

\begin{tabular}{|c|c|c|c|c|}
\hline \multirow[b]{2}{*}{$m / z$} & \multirow[b]{2}{*}{ Identity } & \multicolumn{3}{|c|}{ Ion intensity (counts $\mathrm{mg}^{-1}$ ) } \\
\hline & & Native & Reclaimed & $\begin{array}{l}\text { Reference } \\
\text { eroded }\end{array}$ \\
\hline & & \multicolumn{3}{|c|}{ Phenols } \\
\hline & Phenol & 116268 & 114839 & 118598 \\
\hline 108 & Methylphenol & 84084 & 95507 & 77294 \\
\hline 110 & Dihydroxybenzene & 129121 & 160487 & 62989 \\
\hline 122 & Dimethylphenol & 56245 & 69147 & 38283 \\
\hline 124 & Guaiacol & 73134 & 84598 & 33895 \\
\hline 126 & Trihydroxybenzene & 52796 & 56214 & 23708 \\
\hline 138 & Methylguaiacol & 43030 & 50423 & 19469 \\
\hline 140 & Hydroxyguaiacol & 48619 & 49933 & 34419 \\
\hline 150 & Ethyleneguaiacol & 79823 & 115765 & 35809 \\
\hline 152 & Vanillin & 34439 & 42404 & 17818 \\
\hline 154 & Syringol & 70368 & 57952 & 59375 \\
\hline \multicolumn{2}{|c|}{ Subtotal } & 787997 & 897269 & 521656 \\
\hline & & \multicolumn{3}{|c|}{ Lignin monomers } \\
\hline 164 & Guaiacylpropene & 65657 & 81401 & 24786 \\
\hline & Guaiacylpropane & 59811 & 52287 & 39235 \\
\hline 168 & Vanillic acid & 143365 & 117477 & 108663 \\
\hline 178 & Coniferyl aldehyde & 88235 & 64895 & 50340 \\
\hline 180 & Coniferyl alcohol & 102759 & 83979 & 69750 \\
\hline 182 & Syringyl aldehyde & 189453 & 176000 & 139604 \\
\hline 194 & Ferulic acid & 313404 & 267392 & 209538 \\
\hline & $\begin{array}{l}\text { Syringyl } \\
\text { acetaldehyde }\end{array}$ & 145112 & 131489 & 87098 \\
\hline 208 & Sinapyl aldehyde & 370050 & 334795 & 233065 \\
\hline 210 & Sinapyl alcohol & 157826 & 156549 & 94258 \\
\hline 212 & Syringyl acetic acid & 71395 & 68334 & 39608 \\
\hline \multicolumn{2}{|c|}{ Subtotal } & \multicolumn{2}{|c|}{17070671534597} & 1095944 \\
\hline \multicolumn{2}{|c|}{ Total $^{*}$} & \multicolumn{2}{|c|}{24950642431866} & 1617600 \\
\hline
\end{tabular}

${ }^{*} t$ test (total): native vs reclaimed $p=0.25$; native vs reference eroded $p<0.0001$; reclaimed vs reference eroded $p<0.0001$.

acids $>$ nitriles and other $\mathrm{N}$ compounds $>$ sterols+ steroids > alkyl radicals $>>>$ esters of suberin (Table 16).

An inspection of the mass spectrometry data in Tables $2-16$ shows that relative to the reference eroded Oxisol, the abundance of most chemical classes of compounds was often highest in the native samples, followed by those in the reclaimed soil samples. Interestingly, the abundance of carbohydrates and amino acids were highest in the reclaimed soil (Table 2). The reference eroded samples had the lowest abundance of chemical classes of compounds. According to pairwise $t$ test comparisons, the native soil samples had the highest abundance of lignin dimers, $n$-alkylbenzenes, flavonoids, $n$-diols, $N$-heterocyclics, nitriles, alkyl radicals, and sterols+steroids. The
Table 6. Chemical structures for $m / z$ assigned to lignin dimers in samples obtained from the $0-5 \mathrm{~cm}$ depth of native and reclaimed phases relative to a reference eroded Oxisol.

\begin{tabular}{|c|c|c|c|}
\hline$m / z$ & Structure & $R_{1}$ & $R_{2}$ \\
\hline & \multicolumn{3}{|c|}{ Biphenyl } \\
\hline 246 & & $-\mathrm{H}$ & $-\mathrm{H}$ \\
\hline 260 & & $-\mathrm{CH}_{3}$ & $-\mathrm{H}$ \\
\hline 272 & & $-\mathrm{CH}_{3}$ & $-\mathrm{CH}_{3}$ \\
\hline 274 & & $-\mathrm{CH}_{2} \mathrm{CH}_{3}$ & $-\mathrm{H}$ \\
\hline 286 & & $-\mathrm{CH}=\mathrm{CH}-\mathrm{CH}_{3}$ & $-\mathrm{H}$ \\
\hline 300 & & $-\mathrm{CH}=\mathrm{CH}-\mathrm{CH}_{3}$ & $-\mathrm{CH}_{3}$ \\
\hline 302 & & $-\mathrm{CH}=\mathrm{CH}-\mathrm{CH}_{2}-\mathrm{OH}$ & $-\mathrm{H}$ \\
\hline 316 & & $-\mathrm{CH}=\mathrm{CH}-\mathrm{CH}_{2}-\mathrm{OH}$ & $-\mathrm{CH}_{3}$ \\
\hline 328 & & $-\mathrm{CH}=\mathrm{CH}-\mathrm{CH}_{2}-\mathrm{OH}$ & $-\mathrm{CH}=\mathrm{CH}_{2}$ \\
\hline \multicolumn{4}{|c|}{ Phenylcoumaran } \\
\hline 314 & & $-\mathrm{CH}-\mathrm{CH}-\mathrm{OH}$ & $-\mathrm{H}$ \\
\hline 330 & & $-\mathrm{CH}_{2}-\mathrm{OH}$ & $-\mathrm{OCH}_{3}$ \\
\hline 332 & & $-\mathrm{CH}_{2}-\mathrm{OH}$ & $-\mathrm{OCH}_{3}$ \\
\hline 340 & & $-\mathrm{CH}=\mathrm{CH}-\mathrm{CH}_{3}$ & $-\mathrm{OCH}_{3}$ \\
\hline 342 & & $-\mathrm{CH}=\mathrm{CH}-\mathrm{CH}_{3}$ & $-\mathrm{OCH}_{3}$ \\
\hline 346 & & $-\mathrm{CH}_{2}-\mathrm{CH}_{2}-\mathrm{OH}$ & $-\mathrm{OCH}_{3}$ \\
\hline 356 & & $-\mathrm{CH}=\mathrm{CH}-\mathrm{CH}_{2}-\mathrm{OH}$ & $-\mathrm{OCH}_{3}$ \\
\hline 358 & $\mathrm{O}$ & $-\mathrm{CH}=\mathrm{CH}-\mathrm{CH}_{2}-\mathrm{OH}$ & $-\mathrm{OCH}_{3}$ \\
\hline
\end{tabular}

abundance of phenols + lignin monomers, lipids, alkyl radicals, $\mathrm{N}$-heterocyclics, and esters of suberin was the same in the native and the reclaimed soil samples (Tables 2-16).

Lipids and $N$-heterocyclics are by far the most abundant classes of compounds, with 20-480 times more content than the other chemical classes in the three Oxisol phases. Of the total identified $\mathrm{m} / \mathrm{z}$ signals, lipids and heterocyclic- $N$ comprised 26 and 19\% in the native soil, 21 and 18\% in the reclaimed soil, versus 14 and $11 \%$ in the reference eroded soil, respectively. The abundance of lipids and heterocyclic-N was followed by the abundance of lignin monomers and alkylaromatics, which were highest in the native $>$ reclaimed $>$ reference eroded soil. The abundance of lignin monomers and alkylaromatics was similar and ranged from 5 to $5.9 \%$ in the native and reclaimed soil samples, versus 3.5 to $3.7 \%$ in the reference eroded samples, respectively (Table 16).

The other seven classes of compounds contributed to less than $3.5 \%$ of the total IIs in the three soils, with their abundance usually highest in the native $>$ reclaimed $>$ reference eroded samples. For example, the abundance of sterols, steroids, and esters of suberin represented less than $1 \%$ of the total identified $m / z$ signals (Tables 14 and 15). The latter compound classes are important components of humic substances, plants, soil fungi, and roots. The abundance of these three classes was always highest in the native soil samples. The signals of cholestine $(\mathrm{m} / \mathrm{z} 370)$, cholesterol $(\mathrm{m} / \mathrm{z} 386)$, stigmastine $(\mathrm{m} / \mathrm{z} 394)$, and campesterol $(\mathrm{m} / \mathrm{z} 400)$ were the main contributors 
Table 7. Ion intensities for $m / z$ assigned to lignin dimers in samples obtained from the $0-5 \mathrm{~cm}$ depth of native and reclaimed phases relative to a reference eroded Oxisol.

\begin{tabular}{|c|c|c|c|}
\hline \multirow[b]{2}{*}{$m / z$} & \multicolumn{3}{|c|}{ Ion intensity (counts $\mathrm{mg}^{-1}$ ) } \\
\hline & Native & Reclaimed & $\begin{array}{l}\text { Reference } \\
\text { eroded }\end{array}$ \\
\hline & \multicolumn{3}{|c|}{ Biphenyls } \\
\hline 246 & 158684 & 148805 & 88251 \\
\hline 260 & 141035 & 113526 & 80834 \\
\hline 270 & 106192 & 111130 & 51020 \\
\hline 272 & 110690 & 102226 & 61494 \\
\hline 274 & 127295 & 101295 & 78951 \\
\hline 286 & 59825 & 48794 & 32505 \\
\hline 298 & 110089 & 109307 & 53732 \\
\hline 300 & 68802 & 59427 & 36795 \\
\hline 302 & 67135 & 46687 & 40487 \\
\hline 312 & 45823 & 47863 & 20972 \\
\hline 316 & 81242 & 58347 & 46459 \\
\hline 328 & 41095 & 33487 & 23326 \\
\hline \multirow[t]{2}{*}{ Subtotal } & 1104829 & 965372 & 607009 \\
\hline & \multicolumn{3}{|c|}{ Phenylcoumarans } \\
\hline 314 & 53623 & 45350 & 30168 \\
\hline 330 & 60179 & 44897 & 35185 \\
\hline 332 & 31338 & 61844 & 42745 \\
\hline 340 & 28619 & 22523 & 12937 \\
\hline 342 & 31704 & 27171 & 16574 \\
\hline 346 & 52730 & 50045 & 34499 \\
\hline 356 & 53323 & 44034 & 27638 \\
\hline 358 & 39217 & 25949 & 21675 \\
\hline Subtotal & 390217 & 321812 & 221421 \\
\hline Total* & 1495556 & 1287184 & 828430 \\
\hline
\end{tabular}

${ }^{*} t$ test (total): native vs reclaimed $p=0.009$; native vs reference eroded $p<0.0001$; reclaimed vs reference eroded $p=0.0001$.

to the abundance of sterols and steroids of plant origin. The signals at $m / z 432$ and $m / z 446$ were the main contributors to esters of suberin, denoting the presence of root cell components. Ergosterol at $m / z 396$ represents a fingerprint for soil fungi, and it was highest in the native $>$ reclaimed $>$ reference eroded soil.

\section{Contribution of individual $\mathrm{m} / \mathrm{z}$ signals to key chemical classes}

In the native and reclaimed Oxisol samples, the amounts of carbohydrates was closely associated with the content of hexoses and polysaccharides, and that of amino acids was associated with the content of acidic and aromatic amino acids (Tables 2 and 3).

Lignin monomers were the main contributor (68\%) to the total abundance of phenol+lignin monomer class (Tables 4 and 5), with synapyl aldehyde, ferulic acid, syringyl aldehyde, and sinapyl alcohol being the four
Table 8. Ion intensities for $m / z$ assigned to $n$-alkyl benzenes in samples obtained from the $0-5 \mathrm{~cm}$ depth of native and reclaimed phases relative to a reference eroded Oxisol.

\begin{tabular}{llrlc}
\hline & & \multicolumn{2}{c}{ Ion intensity (counts mg $^{-1}$ ) } \\
\cline { 3 - 5 }$m / z$ & Identity & Native & Reclaimed & $\begin{array}{c}\text { Reference } \\
\text { eroded }\end{array}$ \\
\hline 92 & Methylbenzene & 116539 & 63506 & 75870 \\
106 & Ethylbenzene & 92663 & 62036 & 86544 \\
120 & Propylbenzene & 52330 & 58319 & 58088 \\
134 & Butylbenzene & 89898 & 101976 & 78831 \\
148 & Pentylbenzene & 92816 & 107131 & 62269 \\
162 & Hexylbenzene & 116709 & 151607 & 47917 \\
176 & Heptylbenzene & 97023 & 115997 & 41022 \\
190 & Octylbenzene & 109879 & 114651 & 47910 \\
204 & Nonylbenzene & 183693 & 163464 & 96067 \\
218 & Decylbenzene & 315741 & 277291 & 187496 \\
232 & Undecylbenzene & 332837 & 300947 & 200615 \\
246 & Dodecylbenzene & 158684 & 148805 & 88250 \\
260 & Tridecylbenzene & 141034 & 113526 & 80834 \\
274 & Tetradecylbenzene & 127295 & 101295 & 78950 \\
288 & Pentadecylbenzene & 108994 & 81594 & 69372 \\
302 & Hexadecylbenzene & 67135 & 46687 & 40487 \\
316 & Heptadecylbenzene & 81242 & 58347 & 46459 \\
330 & Octadecylbenzene & 60178 & 44896 & 35185 \\
344 & Nonadecylbenzene & 95432 & 69795 & 48044 \\
358 & Cosylbenzene & 39217 & 25948 & 21675 \\
372 & Uncosylbenzene & 65669 & 46157 & 34912 \\
386 & Docosylbenzene & 45504 & 19588 & 17267 \\
\hline Total* & 2590512 & 2273563 & 1544064 \\
\hline & & &
\end{tabular}

${ }^{*} t$ test (total): native vs reclaimed $p=0.002$; native vs reference eroded $p<0.0001$; reclaimed vs reference eroded $p=0.0002$.

most abundant lignin monomers. Biphenyls contributed the most to the abundance of lignin dimers and they were almost 2.8 times greater than phenylcoumarans, with $\mathrm{m} / z 246$ and $\mathrm{m} / \mathrm{z} 260$ being the most abundant organic species (Tables 6 and 7). The $n$-alkylbenzene class was dominated by the abundance of undecylbenzene $(m / z 232)$ and decylbenzene $(m / z 218)$ species, followed by dodecylbenzene $(\mathrm{m} / \mathrm{z} 246)$ and tridecylbenzene $(m / z 260)$, and other $m / z$ signals (Table 8 ). Table 9 shows that flavanone $(\mathrm{m} / z 224)$ and flavone $(\mathrm{m} / z 222)$ were the most abundant $m / z$ signals, with a concentration $2-3$ times higher than the other five flavonoids. Alcohols such as those shown in signals $m / z 230\left(n-C_{14}\right), m / z 216$ $\left(n-C_{13}\right), m / z 244\left(n-C_{15}\right)$, and $m / z 258\left(n-C_{16}\right)$ were the most abundant diols (Table 10).

Within the soil lipid class, the unsaturated fatty acids (USFAs) with two or more double bonds were the most abundant group of compounds, followed by saturated fatty acids (SFAs), and a group of $m / z$ signals including alkanes and unsaturated fatty acids (Table 11). The USFAs with two or more bonds were almost twice as abundant as the SFAs, and the USFAs with one double 
Table 9. Ion intensities for $m / z$ assigned to flavonoids in samples obtained from the $0-5 \mathrm{~cm}$ depth of native and reclaimed phases relative to a reference eroded Oxisol.

\begin{tabular}{ll}
\hline & \multicolumn{2}{c}{ Ion intensity $\left(\right.$ counts $\left.\mathrm{mg}^{-1}\right)$} \\
\cline { 2 - 2 } Structure & Native $\quad \begin{array}{c}\text { Reference } \\
\text { Reclaimed }\end{array}$ \\
\hline \multicolumn{3}{l}{ Flavones } \\
\hline
\end{tabular}

Flavone, $\mathrm{MW}=222$<smiles></smiles>

360124336701

201844

Apigenin, $\mathrm{MW}=270$<smiles>CCOc1cc(O)cc2c1C(N=[R6]=O)C=C(c1ccc(O)cc1)O2</smiles>

Luteolin, MW=286

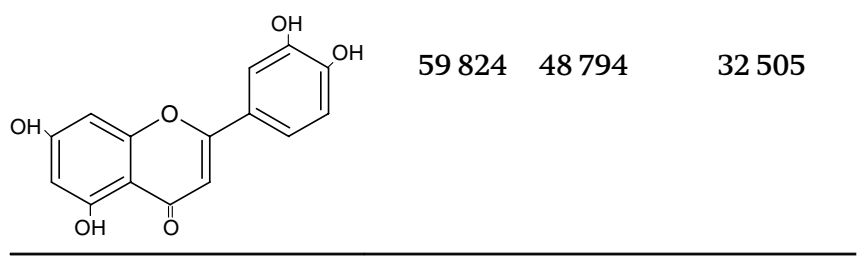

Flavanones

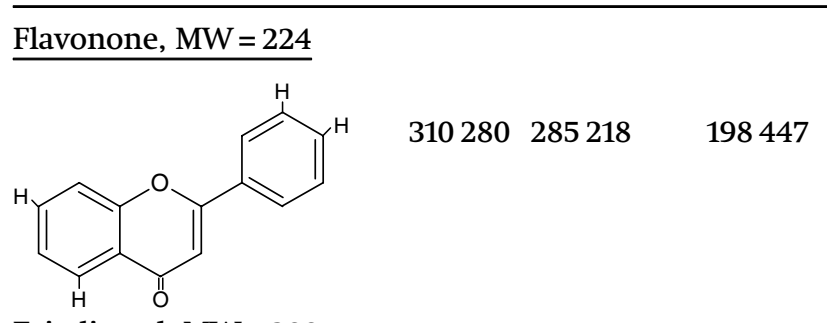

$\underline{\text { Eriodictyol, } \mathrm{MW}=288}$

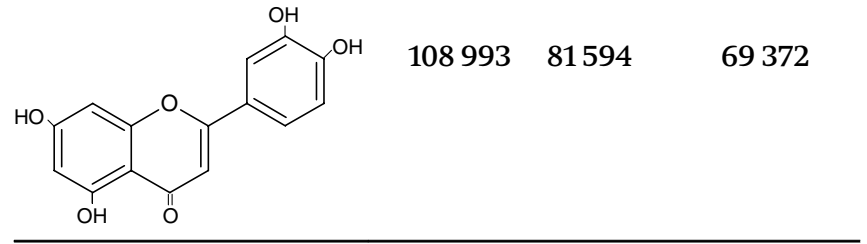

Flavonols

$\underline{\text { Kaempferide, } M W=299}$<smiles>COc1ccc(-c2oc3cccc(O)c3c(=O)c2O)cc1</smiles>

Table 9 (concluded).

\begin{tabular}{|c|c|c|c|}
\hline \multirow[b]{2}{*}{ Structure } & \multicolumn{3}{|c|}{ Ion intensity (counts $\mathrm{mg}^{-1}$ ) } \\
\hline & Native & Reclaimed & $\begin{array}{l}\text { Reference } \\
\text { eroded }\end{array}$ \\
\hline \multicolumn{4}{|c|}{ Quercetin, MW=302 } \\
\hline & 67135 & 46687 & 40488 \\
\hline Total* & 1082467 & 977447 & 624883 \\
\hline
\end{tabular}

${ }^{*} t$ test (total): native vs reclaimed $p=0.016$; native vs reference eroded $p=0.009$; reclaimed vs reference eroded $p=0.0170$.

Table 10. Ion intensities for $m / z$ assigned to $n$-diols in samples obtained from the $0-5 \mathrm{~cm}$ depth of native and reclaimed phases relative to a reference eroded Oxisol.

\begin{tabular}{llccc}
\hline & & \multicolumn{2}{c}{ Ion intensity (counts $\mathrm{mg}^{-1}$ ) } \\
\cline { 3 - 5 }$m / z$ & Identity & Native & Reclaimed & $\begin{array}{l}\text { Reference } \\
\text { eroded }\end{array}$ \\
\hline 202 & $n-C_{12}$ & 248657 & 174485 & 135505 \\
216 & $n-C_{13}$ & 382946 & 285234 & 237077 \\
230 & $n-C_{14}$ & 422629 & 350245 & 246606 \\
244 & $n-C_{15}$ & 365081 & 342679 & 223536 \\
258 & $n-C_{16}$ & 277507 & 280297 & 156887 \\
272 & $n-C_{17}$ & 110689 & 102226 & 61493 \\
286 & $n-C_{18}$ & 59824 & 48793 & 32505 \\
300 & $n-C_{19}$ & 137604 & 118854 & 73590 \\
314 & $n-C_{20}$ & 53623 & 45350 & 30168 \\
328 & $n-C_{21}$ & 41095 & 33487 & 23325 \\
342 & $n-C_{22}$ & 31703 & 27170 & 16574 \\
\hline Total & & 2062558 & 1749390 & 1200476 \\
\hline
\end{tabular}

${ }^{*} t$ test (total): native vs reclaimed $p=0.0090$; native vs reference eroded $p=0.0005$; reclaimed vs reference eroded $p=0.0013$.

bond. Among the USFA with two or more double bonds, heptadecadienoic acid $\left(\mathrm{C}_{17: 2}, \mathrm{~m} / \mathrm{z} 266\right)$, hexadecadienoic acid $\left(C_{16: 2}\right)$, eicosadienoic acid $\left(C_{20: 2}, m / z 308\right)$, linoleic acid $\left(C_{18: 2}, m / z 280\right)$, together with pentadecadienoic $\left(\mathrm{C}_{15: 2}, \mathrm{~m} / \mathrm{z} 238\right)$ and tetradecadienoic acid $\left(\mathrm{C}_{14: 2}, \mathrm{~m} / \mathrm{z} 224\right)$ were the five most abundant species. We assumed that alkanes and USFs with one double bond contributed each with $50 \%$ of the measured abundance for each assigned $m / z$; as the Py-FIMS analytical technique could not separate their exact contributions. Among the SFAs, lauric acid $\left(n-\mathrm{C}_{12}, m / z 200\right)$, myristic acid $\left(n-\mathrm{C}_{14}, m / z 228\right)$, $n-\mathrm{C}_{15}$, palmitic acid $\left(n-\mathrm{C}_{16}, m / z 256\right)$, and margaric acid 
Table 11. Ion intensities for $m / z$ assigned to fatty acids and $n$-alkanes in the $0-5 \mathrm{~cm}$ depth of native and reclaimed phases relative to a reference eroded Oxisol.

\begin{tabular}{|c|c|c|c|c|c|}
\hline \multirow[b]{2}{*}{$m / z$} & \multirow[b]{2}{*}{$\begin{array}{l}\text { Fatty } \\
\text { acid }\end{array}$} & \multirow[b]{2}{*}{ n-Alkane } & \multicolumn{3}{|c|}{ Ion intensity (counts $\mathrm{mg}^{-1}$ ) } \\
\hline & & & Native & Reclaimed & $\begin{array}{l}\text { Reference } \\
\text { eroded }\end{array}$ \\
\hline 46 & $n-C_{1}$ & & 16798 & 6727 & 2924 \\
\hline 58 & $n-C_{2: 1}$ & $n-C_{4}$ & 495252 & 263503 & 297207 \\
\hline 60 & $n-C_{2}$ & & 54801 & 56571 & 10828 \\
\hline 72 & $\mathrm{C}_{3: 1}$ & $n-C_{5}$ & 50024 & 30469 & 31461 \\
\hline 74 & $n-C_{3}$ & & 15106 & 16789 & 4295 \\
\hline 86 & $\mathrm{C}_{4: 1}$ & $n-C_{6}$ & 91725 & 89170 & 38338 \\
\hline 88 & $\mathrm{n}-\mathrm{C}_{4}$ & & 6799 & 10219 & 2443 \\
\hline 100 & $C_{5: 1}$ & $n-C_{7}$ & 34849 & 41326 & 14669 \\
\hline 102 & $n-C_{5}$ & & 7585 & 10597 & 3055 \\
\hline 114 & $\mathrm{C}_{6: 1}$ & $n-C_{8}$ & 37821 & 44978 & 13814 \\
\hline 116 & $n-C_{6}$ & & 29027 & 24385 & 27052 \\
\hline 128 & $\mathrm{C}_{7: 1}$ & $n-C_{9}$ & 80123 & 56035 & 63251 \\
\hline 130 & $n-C_{7}$ & & 26135 & 18349 & 28632 \\
\hline 142 & $\mathrm{C}_{8: 1}$ & $n-\mathrm{C}_{10}$ & 93871 & 69404 & 79725 \\
\hline 144 & $n-C_{8}$ & & 94943 & 978576 & 92222 \\
\hline 156 & $C_{9: 1}$ & $n-C_{11}$ & 123893 & 82197 & 100509 \\
\hline 158 & $n-C_{9}$ & & 108738 & 117679 & 81408 \\
\hline 170 & $C_{10: 1}$ & $n-\mathrm{C}_{12}$ & 184828 & 120676 & 117237 \\
\hline 172 & $n-C_{10}$ & & 123250 & 128370 & 73065 \\
\hline 182 & $\mathrm{C}_{11: 2}$ & & 189453 & 176000 & 139604 \\
\hline 184 & $C_{11: 1}$ & $n-C_{13}$ & 236688 & 175064 & 140268 \\
\hline 186 & $n-\mathrm{C}_{11}$ & & 125105 & 105363 & 40300 \\
\hline 196 & $\mathrm{C}_{12: 2}$ & & 145112 & 131489 & 87098 \\
\hline 198 & $C_{12: 1}$ & $n-C_{14}$ & 288695 & 205205 & 133264 \\
\hline 200 & $n-C_{12}$ & & 220840 & 204359 & 69024 \\
\hline 210 & $\mathrm{C}_{13: 2}$ & & 157826 & 156548 & 94257 \\
\hline 212 & $\mathrm{C}_{13: 1}$ & $n-\mathrm{C}_{15}$ & 71395 & 68334 & 39608 \\
\hline 214 & $n-C_{13}$ & & 153361 & 158214 & 51133 \\
\hline 224 & $\mathrm{C}_{14: 2}$ & & 310280 & 285218 & 198447 \\
\hline 226 & $\mathrm{C}_{14: 1}$ & $n-C_{16}$ & 214664 & 204100 & 119196 \\
\hline 228 & $n-C_{14}$ & & 236725 & 188645 & 116259 \\
\hline 238 & $\mathrm{C}_{15: 2}$ & & 314719 & 280965 & 172700 \\
\hline 240 & $\mathrm{C}_{15: 1}$ & $n-\mathrm{C}_{17}$ & 221109 & 201497 & 132267 \\
\hline 242 & $n-C_{15}$ & & 252669 & 222139 & 126448 \\
\hline 252 & $\mathrm{C}_{16: 2}$ & & 457996 & 327481 & 244732 \\
\hline 254 & $C_{16: 1}$ & $n-\mathrm{C}_{18}$ & 268295 & 236022 & 163315 \\
\hline 256 & $n-C_{16}$ & & 242264 & 232007 & 119088 \\
\hline 266 & $\mathrm{C}_{17: 2}$ & & 542355 & 370542 & 306087 \\
\hline 268 & $\mathrm{C}_{17: 1}$ & $n-C_{19}$ & 239034 & 191078 & 144635 \\
\hline 270 & $n-C_{17}$ & & 212383 & 222260 & 102040 \\
\hline 278 & $\mathrm{C}_{18: 3}$ & & 298698 & 225786 & 144591 \\
\hline 280 & $\mathrm{C}_{18: 2}$ & & 371046 & 267946 & 225979 \\
\hline 282 & $\mathrm{C}_{18: 1}$ & $n-C_{20}$ & 198508 & 166930 & 111306 \\
\hline 284 & $n-C_{18}$ & & 148232 & 141286 & 70517 \\
\hline 292 & $\mathrm{C}_{19: 3}$ & & 207518 & 188041 & 111082 \\
\hline 294 & $\mathrm{C}_{19: 2}$ & & 277281 & 227791 & 158532 \\
\hline 296 & $C_{19: 1}$ & $n-C_{21}$ & 155177 & 131578 & 89524 \\
\hline 298 & $n-C_{19}$ & & 110089 & 109307 & 53732 \\
\hline 306 & $\mathrm{C}_{20: 3}$ & & 186194 & 171196 & 96779 \\
\hline 308 & $\mathrm{C}_{20: 2}$ & & 368270 & 288894 & 158715 \\
\hline 310 & $\mathrm{C}_{20: 1}$ & $n-C_{22}$ & 131254 & 105857 & 61246 \\
\hline 312 & $n-C_{20}$ & & 45822 & 47862 & 20972 \\
\hline 320 & $\mathrm{C}_{21: 3}$ & & 132179 & 123690 & 66721 \\
\hline
\end{tabular}

Table 11 (concluded).

\begin{tabular}{lllrrr}
\hline & & & \multicolumn{3}{c}{ Ion intensity (counts $\mathrm{mg}^{-1}$ ) } \\
\cline { 4 - 6 }$m / z$ & acid & $n$-Alkane & Native & Reclaimed & Reference \\
eroded
\end{tabular}

\begin{tabular}{|c|c|c|c|}
\hline \multicolumn{4}{|c|}{ Type of fatty acid on $n$-alkane } \\
\hline Saturated $n$-fatty acid & 2785227 & 2506066 & 1287979 \\
\hline $\begin{array}{l}\text { Unsaturated fatty } \\
\text { acid with one } \\
\text { double bond }\end{array}$ & 1957458 & 1471679 & 1082303 \\
\hline $\begin{array}{l}\text { Unsaturated fatty } \\
\text { acid with } \geq \text { two } \\
\text { double bonds }\end{array}$ & 4440187 & 3682291 & 2440405 \\
\hline n-Alkanes & 1957458 & 1471679 & 1082303 \\
\hline Total lipids* & 11140330 & 9131715 & 5892990 \\
\hline
\end{tabular}

${ }^{*} t$ test (total): native vs reclaimed $p=0.156$; native vs reference eroded $p<0.0001$; reclaimed vs reference eroded $p=0.0001$.

$\left(n-C_{17}, m / z 270\right)$ were the most abundant species. The species of SFAs with chain lengths $<n-C_{10}$ and for $>n-C_{20}$ to $n-C_{33}$ were the least abundant fatty acids in all three Oxisol samples (Table 11). Table 12 shows that the alkyl radicals identified in the Oxisol ranged from ethyl to octyl, that is, from $C_{2}$ to $C_{8}$. The concentration of alkyl radicals in the reference eroded samples was low $\left(\sim 158000\right.$ counts $\left.\mathrm{mg}^{-1}\right)<$ reclaimed samples $\left(\sim 387000\right.$ counts $\left.\mathrm{mg}^{-1}\right)<$ native samples $(\sim 523000$ 
Table 12. Ion intensities for $m / z$ assigned to alkyl radicals in samples obtained from the $\mathbf{0}-\mathbf{5} \mathrm{cm}$ depth of native and reclaimed phases relative to a reference eroded Oxisol.

\begin{tabular}{llccc}
\hline & & \multicolumn{2}{c}{ Ion intensities (count $\mathrm{mg}^{-1}$ soil) } \\
\cline { 3 - 5 } & & Reclaimed & $\begin{array}{l}\text { Reference } \\
\text { eroded }\end{array}$ \\
\hline $\mathrm{m} / z$ & Identity & Native & Re & 28289 \\
29 & Ethyl & 199390 & 69795 & 70783 \\
43 & Propyl & 291972 & 208986 & 13766 \\
57 & Butyl & 29550 & 27503 & 21180 \\
71 & Pentyl & 31664 & 35714 & 28444 \\
85 & Hexyl & 49564 & 69613 & 8536 \\
99 & Heptyl & 21057 & 31854 & 8720 \\
113 & Octyl & 16051 & 20818 & 158120 \\
\hline Total* & & 522856 & 387345 &
\end{tabular}

${ }^{*} t$ test (total): native vs reclaimed $p=0.147$; native vs reference eroded $p=0.048$; reclaimed vs reference eroded $p=0.027$.

counts $\mathrm{mg}^{-1}$ ). These alkyl radicals are usually generated by chemical and (or) enzymatic reactions from aliphatic side chains bonded to long aliphatic chains, especially near double bonds, in fatty acids, alkanes, $n$-diols, and (or) $n$-alkyl esters. It is also possible that the free alkyl radicals were formed during pyrolysis or in the electromagnetic field of the mass spectrometer.

The $N$-heterocyclics appeared as the second most abundant class of chemical compounds (Table 13). The abundance of $\mathrm{N}$-heterocyclic groups decreased in the following order: pyrazole, substituted pyrazoles and imidazoles $>$ pyrazines and substituted pyrazines $>$ carbazole and substituted carbazoles $>$ quinolines and benzoquinolines $>>$ pyridine and substituted pyridines $>$ indoles and substituted indoles $>$ nitriles $>$ phenylpyridine and substitutes. The first four groups of N-heterocyclics were from two to three times more abundant than the other five groups of $\mathrm{N}$-heterocyclics identified in the three Oxisol treatments (Table 13). In the pyrazole and imidazoles group, methylpyrazole derivative species were the most abundant. Examples of the latter involves compounds such as hydroxypyrazole $(m / z 84)$, dimethylpyrazole $(m / z 96)$, and tetramethyl-heptylpyrazole $(m / z \quad 222)$. In all three soils and among the pyrazine and substituted pyrazines, pentamethyl-pentylpyrazine, pentamethylbutylpyrazine, and pentamethyl-propylpyrazine were the most abundant species of all $\mathrm{N}$-heterocyclic compounds. Various species involving methyl derivatives of carbazole, quinolines, phenylpyridines, and indoles were identified frequently and contributed most to the molecular abundance in the groups of $\mathrm{N}$-heterocyclics (Table 13).

\section{Discussion}

Thermograms of OM volatilization are essentially differential thermal analysis curves, which provide information on the thermal stability of chemical components in SOM during pyrolysis. Differences in the exothermic maxima of SOM volatilization indicate the degree to which components of different molecular complexity have been influenced by microbial processing and physicochemical associations of $\mathrm{OM}$ with inorganic components. For example, and in relative terms, the presence of a single thermostable component $\left(>450{ }^{\circ} \mathrm{C}\right)$ in the native and reference eroded samples indicates that SOM is highly humified and decomposed and is strongly bound to clay minerals. In addition, the thermally stable SOM pool may also represent complex and polymerized chemical structures (Schnitzer and Monreal 2011). Conversely, the thermolabile peaks at 320 or $<400{ }^{\circ} \mathrm{C}$ in the reclaimed soil samples indicates the SOM bound less strongly to clay minerals. The presence of thermolabile and less humified OM involving carbohydrates, amino acids, and sterols reflects to a large extent contributions to SOM from pools of fresh $\mathrm{OM}$ added via plant residues and sewage sludge in the reclaimed Oxisol.

In general, most SOM in thermolabile and thermostable pools is found in organo-mineral complexes in clay and aggregate fractions, and such OM cannot be separated easily from clay minerals, as reported by Chenu and Plante (2006). The association between organic and mineral constituents in microaggregate and clay fractions increases the turnover time of SOM (Monreal et al. 1997, 2010). Soil humic substances, which can make up $60-80 \%$ of the total SOM, are mostly stabilized as calcium humates and in reactions with crystalline and amorphous mineral and metal species. For example, the accumulation of humic substances in the fine clay fraction is favoured by expandable phyllosilicates in a Chernozemic soil of Canada (Schnitzer and Kodama 1977). In Podzolic soils, simple and mobile humic substances are preferentially bonded by Fe and aluminum inorganic species (Tyurin 1953). Oxisols in Brazil cover approximately $60 \%$ of its territory, have an acid $\mathrm{pH}$, are highly weathered, and are dominated by variable-charge components, with relatively low amounts of SOM and variable clay content (Moreira et al. 2008; Ferreira et al. 2010).

In our research study, we focused on the chemical molecular components of OM in whole Oxisol samples. Although we did not study soil organo-mineral complexes in the Oxisol, we assumed that most OM was bound in stable organo-mineral complexes, especially associated with the mineral species of $\mathrm{Fe}, \mathrm{Al}$, and silicates of the Oxisol (Table 1). The studied Oxisol presented a high clay content, especially in the native and reclaimed samples, but clay was also present in the reference eroded soil. Complementary chemical analyses of key inorganic components show the presence of $\mathrm{Fe}, \mathrm{Al}$, and silicon ( $\mathrm{Si}$ ) mineral species and suggest that SOM in the Oxisol is mostly bound to these mineral species but is also bound to extractable species of $\mathrm{Al}$ oxide and 
Table 13. Ion intensities for $m / z$ assigned to $N$-heterocyclics in samples obtained from the $0-5 \mathrm{~cm}$ depth of native and reclaimed phases relative to a reference eroded Oxisol.

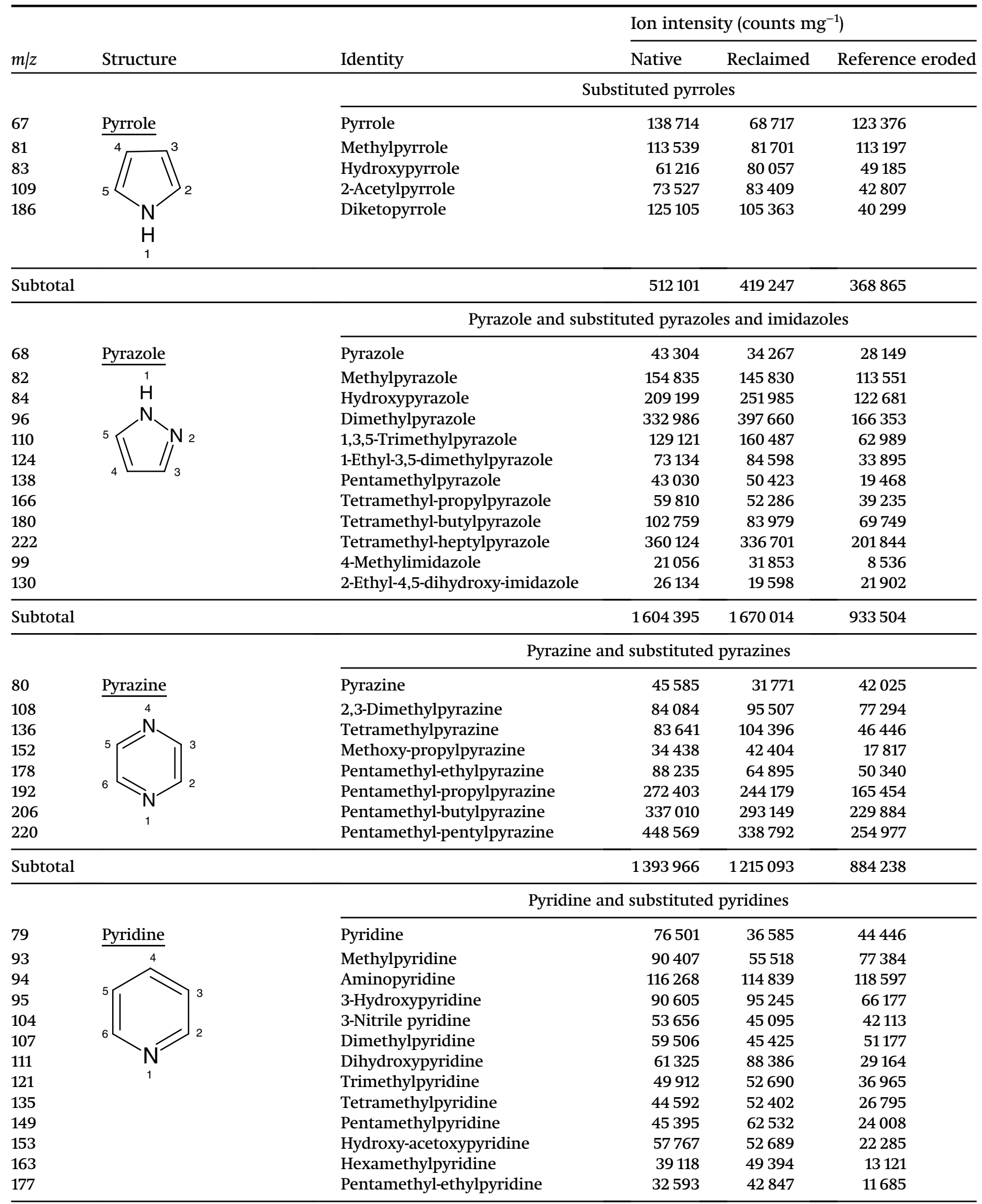


Table 13 (continued).

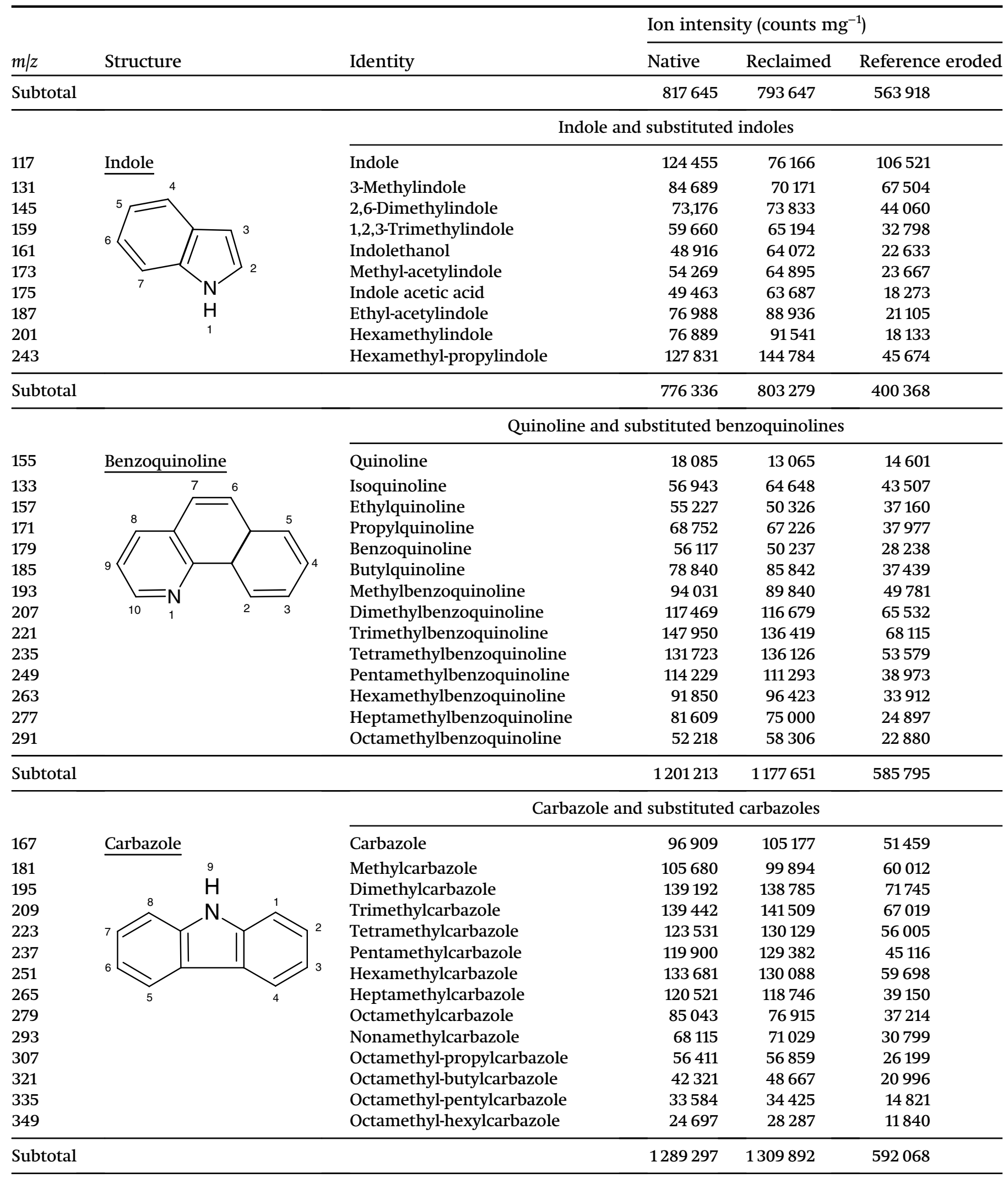


Table 13 (concluded).

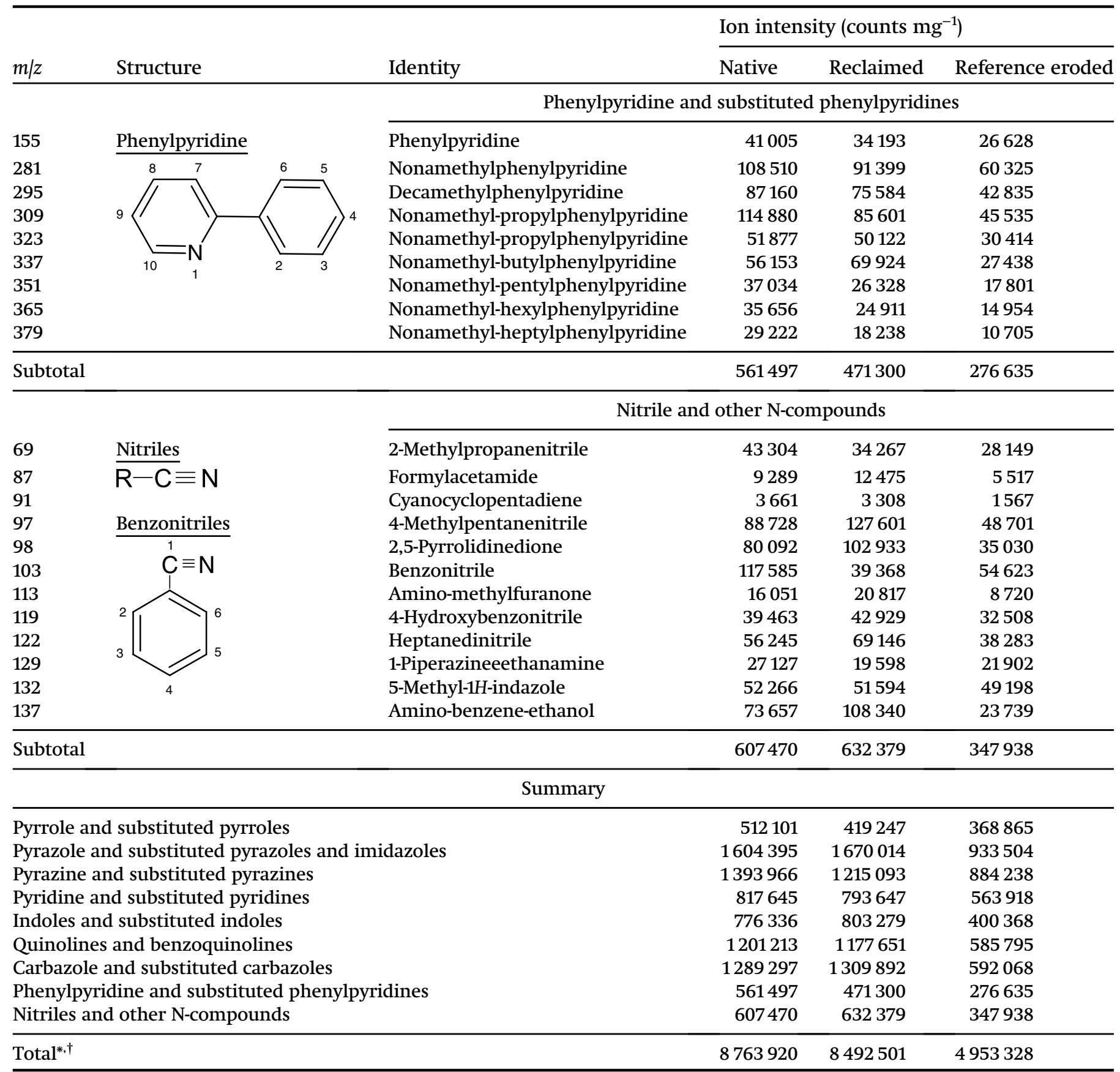

${ }^{*} t$ test for total N-heterocyclics: native vs reclaimed $p=0.160$; native vs eroded $p<0.0001$; reclaimed vs eroded $p<0.0001$.

${ }^{\dagger} t$ test for total nitriles: native vs reclaimed $p=0.46$; native vs reference eroded $p<0.0027$; reclaimed vs reference eroded $p=0.0170$.

hydroxides. The lower content of $\mathrm{Al}+\mathrm{H}$ species in the reference eroded samples than in the native or reclaimed soil indicates not only differences in the content of these chemical species but also differences in the degree of chemical weathering. The studied native Oxisol that originated from sediments dating from the Tertiary Period (e.g., phyllite and siltstone) has high levels of $\mathrm{Al}+\mathrm{H}$, thus it is intensely weathered and leached.
The $\mathrm{Al}$ species extracted with calcium chloride solution $\left(0.01 \mathrm{~mol} \mathrm{~L}^{-1}\right)$ form rather stable complexes with SOM by reacting primarily with carboxyl groups and to a lesser extent with phenolic hydroxyl groups. The amount of $\mathrm{Al}-\mathrm{OM}$ complex formed is dependent on $\mathrm{pH}$ and $\mathrm{Al}^{3+}$ concentration in solution (Bloom 1981; Hargrove and Thomas 1982). In the reclaimed soil, the content of $\mathrm{Al}+\mathrm{H}$ was lower than in the native soil, which 
Table 14. Ion intensities for $m / z$ assigned to sterols and steroids in samples obtained from the $0-5 \mathrm{~cm}$ depth of native and reclaimed phases relative to a reference eroded Oxisol.

\begin{tabular}{|c|c|c|c|c|}
\hline \multirow[b]{2}{*}{$m / z$} & \multirow[b]{2}{*}{ Identity } & \multicolumn{3}{|c|}{ Ion intensity (counts $\mathrm{mg}^{-1}$ ) } \\
\hline & & Native & Reclaimed & $\begin{array}{l}\text { Reference } \\
\text { eroded }\end{array}$ \\
\hline 370 & Cholestine & 65669 & 46357 & 34912 \\
\hline 386 & Cholesterol & 45504 & 19587 & 17267 \\
\hline 394 & Stigmastene & 62113 & 14832 & 5475 \\
\hline 396 & Ergosterol & 37731 & 23767 & 7612 \\
\hline 400 & Campesterol & 43323 & 28916 & 24417 \\
\hline 410 & Stigmasterol & 19755 & 10474 & 5454 \\
\hline 412 & Stigmasterol & 20940 & 15723 & 13667 \\
\hline 414 & $\beta$-Sitosterol & 19629 & 19308 & 17482 \\
\hline 416 & $\begin{array}{l}\text { Dehydro- } \beta \text { - } \\
\text { sitosterol }\end{array}$ & 16778 & 12038 & 5929 \\
\hline 426 & $\begin{array}{l}\text { D:A Friedooleanan- } \\
\text { 3-one }\end{array}$ & 10921 & 14414 & 6928 \\
\hline 430 & $\alpha$-Tocopherol & 9391 & 7690 & 5382 \\
\hline Total & & 348002 & 217868 & 137742 \\
\hline
\end{tabular}

${ }^{*} t$ test (total): native vs reclaimed $p=0.008$; native vs reference eroded $p=0.002$; reclaimed vs reference eroded $p=0.0006$.

is also in agreement with the fact that after mechanically removing the top $8.6 \mathrm{~m}$, the experimental plots were established on saprolite, a less weathered regolith present in the original native Oxisol (Kitamura et al. 2008; Taboada-Castro et al. 2009). Complementary information also shows that the amount of extractable $\mathrm{Fe}$ and $\mathrm{Al}$ influences the stabilization of soil $\mathrm{C}$ and its availability to soil microorganisms in non-volcanic and volcanic ash derived soils (Monreal et al. 1981; Parfitt and Parshotam 2002; Matus et al. 2014). Thus, our data suggest that most SOM may be found as organo-mineral complexes in the clay fraction, where $\mathrm{Fe}_{2} \mathrm{O}_{3}, \mathrm{Al}$ oxides (i.e., gibbsite), and kaolinite predominate (Guilherme and Anderson 1998). The surface functional groups of inorganic and organic matter species in Oxisols help form strong organo-mineral complexes and in the adsorption of ions and heavy metals (Sposito 1984; Naidu et al. 1994), especially in the clay fraction than in the sand fraction (Chimchart et al. 2013). Future research is warranted on the organo-mineral complexes in the clay fraction of the Oxisol to examine the influence of pedogenesis and the soil reclamation practice on the type of chemical compounds and distribution of SOM at the nano- and microscales. To present, the temporal and spatial organization in architectural units and mechanisms of interactions of natural polymers of humic substances and their coverage of soil mineral surfaces are, to a large extent, still unclear (Dümig et al. 2012).
Table 15. Ion intensities for $m / z$ assigned to esters of suberin in samples obtained from the $0-5 \mathrm{~cm}$ of native and reclaimed phases relative to a reference eroded Oxisol.

\begin{tabular}{|c|c|c|c|}
\hline \multirow[b]{2}{*}{$m / z$} & \multicolumn{3}{|c|}{ Ion intensity (counts $\mathrm{mg}^{-1}$ ) } \\
\hline & Native & Reclaimed & $\begin{array}{l}\text { Reference } \\
\text { eroded }\end{array}$ \\
\hline 432 & 9645 & 6663 & 3594 \\
\hline 446 & 6860 & 5869 & 3263 \\
\hline 460 & 3346 & 3296 & 1289 \\
\hline 474 & 1832 & 1744 & 1320 \\
\hline 488 & 1593 & 1275 & 626 \\
\hline Total* & 23276 & 18847 & 10092 \\
\hline
\end{tabular}

In addition, our results showed that thermally stable lipids, alkylaromatics, and $\mathrm{N}$-heterocyclics volatilized at $>450{ }^{\circ} \mathrm{C}$ from the Oxisol samples, results that parallel the thermal stability shown by the same chemical classes of compounds observed in old SOM (i.e., $450-1200$ years) residing in the clay and nano-size fractions of a thin Black Chernozem, and microaggregates $<50 \mu \mathrm{m}$ of a Gleysol of Canada (Monreal et al. 1997, 2010). From our data, we hypothesize that thermostable SOM classes (i.e., alkylaromatics, lipids, phenols+lignin monomers) in the Oxisol are associated with $\mathrm{Fe}, \mathrm{Al}$, and Si mineral species. Noteworthy, our findings on thermostable SOM are consistent with the hypothesis that alkylaromatics conform the central structural unit (i.e., backbone) of soil humic substances, to which other classes of compounds, such as lipids and phenols, are bound by covalent bonding during the biotic synthesis of soil humic substances via polyketides (Schnitzer and Monreal 2011). As determined by Py-FIMS, the native Oxisol presented about 100 times higher total molecular IIs than a Dark Brown Chernozem developed under native grassland, even though both soils have similar $C$ content but with different pedogenetic histories (Schulten et al. 1995).

Figure 3 represents a simple model system that integrates data obtained from the elemental analysis, thermograms, and mass spectra during the chemical characterization of SOM by Py-FIMS. In Fig. 3, the x-axis represents the degree of physicochemical stabilization of SOM to colloidal surfaces of Fe-, Al-, and Si-containing minerals, and the y-axis represents the degree of humification of plant residues and dead microorganisms by active soil organisms. The curved dashed lines represent continuum domains that link biotic and abiotic processes in time and space. Figure 3 shows that SOM in the $0-5 \mathrm{~cm}$ depth of the reference eroded soil is found at the extreme of the $\mathrm{x}$-axis, this is, being largely stabilized 
Table 16. Summary of total ion intensities for $m / z$ assigned to 13 chemical classes of compounds in the $0-5 \mathrm{~cm}$ depth of native and reclaimed phases relative to a reference eroded Oxisol.

\begin{tabular}{|c|c|c|c|c|c|c|}
\hline \multirow[b]{3}{*}{ Chemical class } & \multicolumn{6}{|c|}{ Total ion intensity } \\
\hline & \multicolumn{2}{|l|}{ Native } & \multicolumn{2}{|l|}{ Reclaimed } & \multicolumn{2}{|c|}{ Reference eroded } \\
\hline & (counts $\mathrm{mg}^{-1}$ ) & (\%) & (counts $\mathrm{mg}^{-1}$ ) & (\%) & (counts $\mathrm{mg}^{-1}$ ) & (\%) \\
\hline Carbohydrates & 1441288 & 3.3 & 1621471 & 3.7 & 806179 & 1.8 \\
\hline Amino acids & 643381 & 1.5 & 747673 & 1.7 & 407780 & 0.9 \\
\hline Lignin monomers* & 2495064 & 5.7 & 2431866 & 5.6 & 1617600 & 3.7 \\
\hline Lignin dimers & 1495558 & 3.4 & 1287183 & 2.9 & 828429 & 1.9 \\
\hline n-Alkylbenzenes & 2590513 & 5.9 & 2273764 & 5.2 & 1544064 & 3.5 \\
\hline Flavonoids & 1082467 & 2.5 & 977447 & 2.2 & 624883 & 1.4 \\
\hline$n$-Diols & 2062558 & 4.7 & 1749394 & 4.0 & 1200472 & 2.7 \\
\hline Lipids $^{\dagger}$ & 11140331 & 25.5 & 9131714 & 20.9 & 5892989 & 13.5 \\
\hline $\mathrm{N}$-Heterocyclics & 8156450 & 18.7 & 7860123 & 18.0 & 4605390 & 10.5 \\
\hline Nitrile and other $N$-compounds & 607470 & 1.4 & 632379 & 1.4 & 347938 & 0.8 \\
\hline Alkyl radicals & 522856 & 1.2 & 387345 & 0.9 & 158120 & 0.4 \\
\hline Sterols and steroids & 348002 & 0.8 & 217868 & 0.5 & 137742 & 0.3 \\
\hline Esters of suberin & 23276 & 0.1 & 18847 & 0.0 & 10092 & 0.0 \\
\hline Total assigned $\ddagger$ & 32609212 & 74.6 & 29337072 & 67.1 & 18181078 & 41.6 \\
\hline TII (15-900 m/z) & 43725787 & 100 & 37249467 & 100 & 22278894 & 100 \\
\hline Volatile matter (\%) & & 11 & & 7 & & 5 \\
\hline
\end{tabular}

*Phenols + lignin monomers.

${ }^{\dagger}$ Lipids $=$ fatty acids + alkanes.

${ }^{\ddagger} t$ test (total): native vs reclaimed $p=0.06$; native vs reference eroded $p=0.01$; reclaimed vs reference eroded $p=0.007$.

Fig. 3. The degree of humification and physiochemical stabilization of soil organic matter in the $0-5 \mathrm{~cm}$ depth of the native, reclaimed, and reference eroded Oxisol.

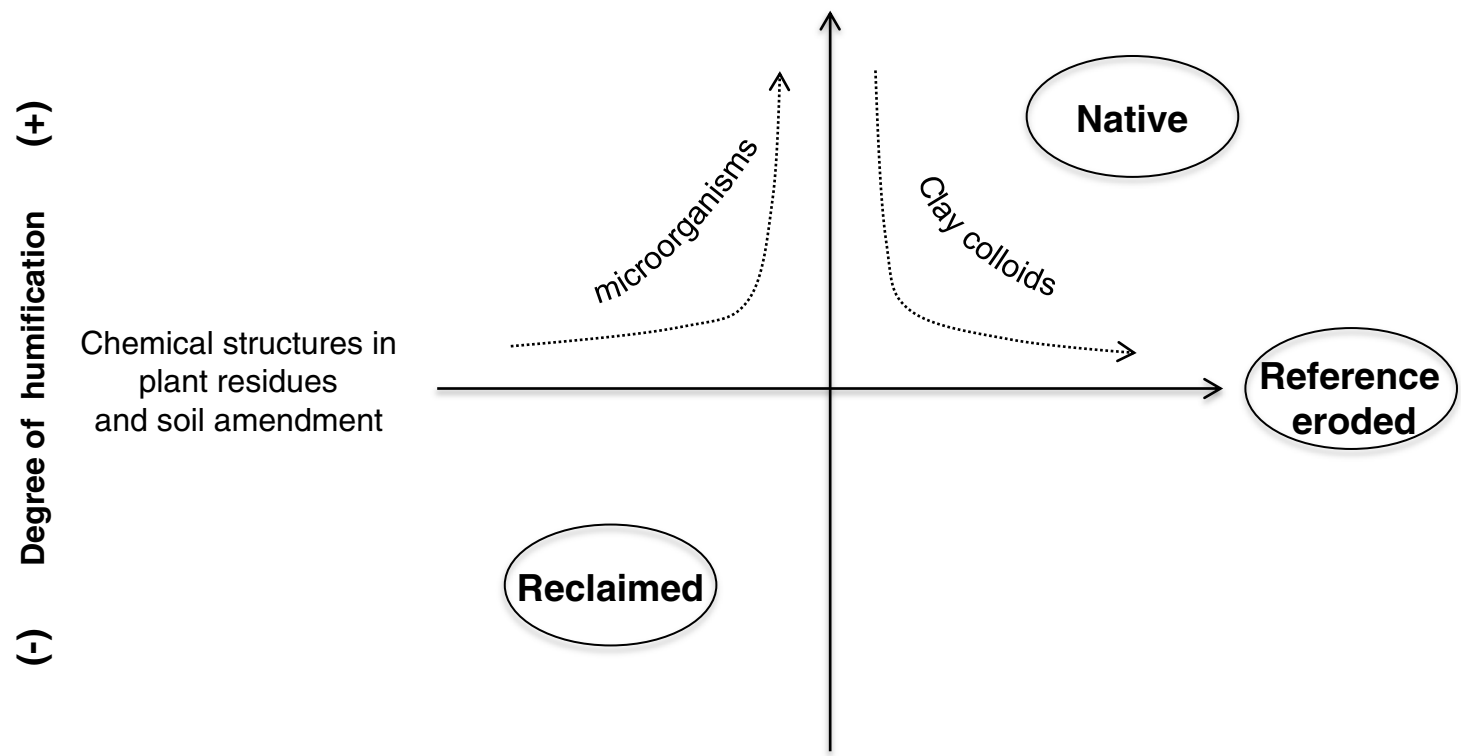

$(-)$ Degree of physico-chemical stabilization $\quad(+)$

Published by NRC Research Press 
by physicochemical reactions to inorganic minerals. The SOM in the reference eroded soil reflects mostly the presence of OM present in the saprolite before the removal of the top $8.6 \mathrm{~m}$ of soil material, as this reference soil has no $C$ inputs such as plant or other organic residues. In addition, microbial humification processes would be negligible during the first 8 years of the experiment. Thus, SOM in the reference eroded soil is likely associated with old SOM leached over thousands of years from the A horizon, and less likely associated with rhizodeposition from native species or biotic humification, as indicated by the soil $\mathrm{C} / \mathrm{N}$ ratio, and the small amount of microbial biomass indicated by the low abundance of ergosterol ( $m / z$ 396) (Table 14), an indicator of soil fungi (Montgomery et al. 2000), and esters of suberin, indicators of root polymer components (Table 15). In the native Oxisol, most SOM in the A horizon appears to be highly humified by microbial processing but also strongly bound to inorganic surfaces during pedogenesis, as indicated by $\mathrm{C} / \mathrm{N}$ ratios and the thermal stability of SOM. Interestingly, the stable and possibly old SOM appears to be associated with structures of alkylaromatics, phenols, and lignin monomers and dimers, with contribution of $\mathrm{N}$-heterocyclics, as indicated by Py-FIMS. In comparison, the SOM in the reclamation treatment represents, to a large extent, the effects of fresh organic residues returned by trees and grasses, roots, plus those in the sewage sludge. This SOM appears with relatively lower degree of microbial humification and physical stabilization than the SOM found in the native Oxisol, as indicated by the $\mathrm{C} / \mathrm{N}$ ratio, the thermal evolution of volatilized chemical compounds, and the existing slow weathering regime. The abundance of thermolabile pools of carbohydrates, amino acids, and sterols contributed significantly to the SOM in the reclaimed soil. The interpretation of the main biotic and abiotic processes depicted in Fig. 3 shows the main influences of pedogenesis and soil reclamation on SOM content and chemical quality. These results show that the relative contributions of humification and abiotic stabilization processes on the chemical structures of SOM in the three Oxisol treatments.

\section{Conclusions}

Data from the elemental and Py-FIMS analysis show that relative to the reference eroded soil samples, total organic $\mathrm{C}$ and $\mathrm{N}$ contents in the top $5 \mathrm{~cm}$ of soil were highest in the native soil, followed by the reclaimed soil samples. The SOM in the surface layer of the reference eroded soil was mostly bound to inorganic colloids, with little influence of soil microorganisms. In the native treatment, SOM appeared to be highly humified and strongly bound to inorganic minerals, reflecting the long-term effect of biotic and abiotic pedogenetic processes. In the reclaimed soil, the chemistry of SOM reflects $\mathrm{C}$ and $\mathrm{N}$ inputs derived from fresh plant residues and sewage sludge, and reflects a low degree of humification and physicochemical stabilization. Humified and thermally stable SOM involved mostly alkylaromatics, lipids, phenols+lignin monomers, lignin dimers, and $\mathrm{N}$-heterocyclics. Conversely, thermolabile pools of SOM involved mostly carbohydrates, amino acids, and sterols, chemical classes that predominate the reclaimed Oxisol. Relative to the reference eroded and reclaimed soil samples, the native Oxisol presented a higher abundance of lignin dimers, $n$-alkylbenzenes, flavonoids, $n$-diols, $N$-heterocyclics, nitriles, alkyl radicals, and sterols plus steroids.

\section{Acknowledgements}

We thank the financial contributions made to this project by Universidade Estadual Paulista, the Coordinação de Apperfeiçoamento de Pessoal de Nivel Superior (CAPES), Brazil, and Agriculture and Agri-Food Canada. The analyses of soil samples by Py-FIMS were conducted by P. Leinweber and Kai-UweEckhardt of Rostock University.

\section{References}

Alves, M.C., and Suzuki, L.G.A.S. 2007. Densidade do solo e infiltração de águacomoindicadores da qualidadefísica de um latossolo Vermelho Distrófico em recuperação. Rev. Bras. Ciênc. Solo. 31: 617-625.

Bloom, R.P. 1981. Metal-organic matter interactions in soil. In Chemistry in the soil environment. ASA Spec. Publ. 40. Edited by R.A. Dowdy. American Society of Agronomy, Madison, WI. pp. 129-150.

Bonini, C.S.B., Dias, R.S., Alves, M.C., Abreu, C.A., Vásquez, E.V., and Paz-Ferreiro, J. 2015. Micronutrient content of a revegetated saprolite exposed by excavation of an Oxisol. Commun. Soil Sci. Plant Anal. 46: 283-295. doi:10.1080/ 00103624.2014.989045.

Chenu, C., and Plante, A.F. 2006. Clay-sized organo-mineral complexes in a cultivation cronosequence: revisiting the concept of the primary organo-mineral complex. Eur. J. Soil Sci. 57: 596-607.

Chimchart, B., Kheoruenromne, I., Suddhiprakarn, A., and Sparks, D.L. 2013. Role of organic matter on charge behaviour of oxisols and ultisols under tropical Savanna and tropical monsoon climates of Thailand. Soil Sci. 178: 540-549. doi:10.1097/SS.0000000000000017.

Dexter, A.R. 2004. Soil physical quality: part I. Theory, effects of soil texture, density, and organic matter, and effects on root growth. Geoderma. 120: 201-214. doi:10.1016/j.geoderma .2003.09.004

Dümig, A., Werner, H., Stephens, W.M., and Kögel-Knabener, I. 2012. Clay fractions from a soil chronosequence after glacier retreat reveal the initial evolution of organo-mineral associations. Geochim. Chosmochim. Acta. 85: 1-18.

Empresa Brasileira de Pesquisa Agropecuária - EMBRAPA. 1997. Manual de métodos de análise de solo, 2rd ed. Centro Nacional de Pesquisa de Solos, Rio de Janeiro, Brasil. 212 p.

Empresa Brasileira de Pesquisa Agropecuária - EMBRAPA. 2013. Sistema brasileiro de classificação de solos, 3rd ed. Rev. Ampl., Brasília, Brasil. 353 p.

Fearnside, P.M. 1993. Deforestation in Brazilian Amazonia: the effect of population and land tenure. Ambio. 22: 537-545.

Feigl, B.J., Melillo, J., and Cerri, C.C. 1995. Changes in the origin and quality of soil organic matter after pasture introduction 
in Rondônia (Brazil). Plant Soil. 175: 21-29. doi:10.1007| BF02413007.

Ferreira, C.A., Silva, A.C., Torrado, P.V., and Rocha, W.W. 2010. Genesis and classification of Oxisols in a highland toposequence of the upper Jequitinhonha Valley (MG). Rev. Bras. Ciênc. Solo. 34: 195-209.

Ferreira, D.F. 2008. Sisvar: versão 4.2. Um programa para análises e ensino de estatística. Revista Symp. 6: 36-41.

Guilherme, L.R., and Anderson, S.J. 1998. Copper sorption kinetics and sorption hysteresis in two oxide-rich soils (Oxisols). Effect of phosphate pretreatment. Chap. 9. In Adsorption of metals by geomedia. Variables, mechanisms and model applications. Edited by E.A. Jenne. Academic Press, San Diego, CA. pp. 210-229.

Hargrove, W.L., and Thomas, G.W. 1982. Conditional formation constants for aluminum-organic matter complexes. Can. J. Soil Sci. 62: 571-575. doi:10.4141/cjss82-064.

Hempfling, R., and Schulten, H.-R. 1990. Chemical characterization of organicmatter in forest soils by Curie-point pyrolysisfield ionization mass spectrometry.Org. Geochem. 15: 131-145. doi:10.1016/0146-6380(90)90078-E.

Hernández, R.M., and López, D. 2002. Microbial biomass, mineral nitrogen y carbon content in savanna soil aggregates under conventional and no-tillage. Soil Biol. Biochem. 34: 1563-1570.

Isaac, M.E., Gordon, A.M., Thevathasan, N., Oppong, S.K., and Quashie-Sam, J. 2005. Temporal changes in soil carbon and nitrogen in West African multistrata agroforestry systems: a chronosequence of pools and fluxes. Agrofor. Syst. 65: 2331. doi:10.1007/s10457-004-4187-6.

Johnson, M.J., Lee, K.Y., and Scow, K.M. 2003. DNA fingerprinting reveals links among agricultural crops, soil properties, and the composition of soil microbial communities. Geoderma. 114: 279-303. doi:10.1016/S0016-7061(03)00045-4.

Kitamura, A., Alves, M.C., Suzuki, L.G.A.S., and Gonzalez, A.P. 2008. Recuperação de um solo degradado com a aplicação de adubos verdes e lodo de esgoto. Rev. Bras. Ci. Solo. 32: 405-416. doi:10.1590/S0100-06832008000100038.

Kögel, I., Hempfling, R., Zech, R., Hatcher, P.G., and Schulten, H.-R. 1988. Chemical compositionof the organic matter in forest soils. I. Forest litter. Soil Sci. 146: 126-136.

Lannes, L.S., Bustamante, M.M.C., Edwards, P.J., and Venterink, H.O. 2012. Alien and endangered plants in the Brazilian Cerrado exhibit contrasting relationships with vegetation biomass and N: P stoichiometry. New Phytol. 196: 816-823. doi:10.1111/j.1469-8137.2012.04363.x.

Lavelle, P., and Pashanasi, B. 1989. Soil macrofauna and land management in Peruvian Amazonia (Yurimaguas, Loreto). Pedobiologia. 33: 283-291.

Matus, F., Rumpel, C., Neculma, R., Panichini, M., and Mora, M.L. 2014. Soil carbon storage and stabilization in andic soils: a review. Catena. 120: 102-110. doi:10.1016/j.catena.2014 .04.008.

Monreal, C.M., Etchevers, J.D., Acosta, M., Hidalgo, C., Padilla, J., López, R.M., Jiménez, L., and Velázquez, A. 2005. A method for measuring above- and below-ground C stocks in hillside landscapes. Can. J. Soil Sci. 85: 523-530. doi:10.4141/ S04-086.

Monreal, C.M., McGill, W.B., and Etchevers, J. 1981. Internal nitrogen cycling compared in surface samples of an Andept and a Mollisol. Soil Biol. Biochem. 13: 451-454. doi:10.1016/ 0038-0717(81)90033-X.

Monreal, C.M., and Schnitzer, M. 2013. The chemistry and biochemistry of organic components in the soil solutions of wheat rhizospheres. Vol. 121. Advances in Agronomy. Edited by D.L. Sparks. pp. 179-251.

Monreal, C.M., and Schnitzer, M. 2015. Labile organic matter in soil solution: II. Separation and identification of metabolites from plant-microbial communication in soil solutions of wheat rhizospheres. In Labile organic matter compositions, function, and significance in soil and the environment. Edited by Z. He and F. Wu. Soil Science Society of America, Madison, WI. doi:10.2136/sssaspecpub62.2014 .0074 .

Monreal, C.M., Schulten, H.-R., and Kodama, H. 1997. Age, turnover and molecular diversity of soil orgaqnic matter in aggregates of a Gleysol. Can. J. Soil Sci. 77: 379-388. doi:10.4141/ S95-064.

Monreal, C.M., Sultan, Y., and Schnitzer, M. 2010. Soil organic matter in nano-scale structures of a cultivated Black Chernozem. Geoderma. 159: 237-242. doi:10.1016/j. geoderma.2010.07.017.

Monreal, C.M., Zentner, R.P., and Robertson, J.A. 1995. The influence of management on soil loss and yield of wheat in Chernozemic and Luvisolic soils. Can. J. Soil Sci. 75: 567574. doi:10.4141/cjss95-080.

Montgomery, H., Monreal, C.M., Young, J.C., and Seifert, K. 2000. Determination of soil fungal biomass from soil ergosterol analyses. Soil Biol. Biochem. 32: 1207-1217. doi:10.1016/ S0038-0717(00)00037-7.

Moreira, C.S., Casagrande, J.S., Ferracciú, L.R., de Camargo, O.A., and Berton, R.S. 2008. Niquel adsorption in two Oxisols and an Alfisol as affected by $\mathrm{pH}$, nature of electrolyte, and ionic strength of soil solution. J. Soils Sed. 8: 442-451. doi:10.1007/s11368-008-0048-7.

Naidu, R., Bolan, N.S., Kookana, R.S., and Tiller, K.G. 1994. Ionic strength and $\mathrm{pH}$ effects on the sorption of cadmium and the surface charge of soils. Eur. J. Soil Sci. 45: 419-429. doi:10.1111/ j.1365-2389.1994.tb00527.x.

Parfitt, R.L., and Parshotam, A. 2002. Carbon turnover in two soils with contrasting mineralogy under long-term maize and pasture. Aust. J. Soil Res. 40: 127-136. doi:10.1071/ SR00105.

Paz-Ferreiro, J., and Alves, M.C. 2012. Revegetation and soil management effects on chemical properties of a saprolite resulting from deep soil removal. Comm. Soil Sci. Plant Anal. 43: 387-398. doi:10.1080/00103624.2012.641796.

Schnitzer, M., and Kodama, H. 1977. Reactions of minerals with soil humic substances. In Minerals and their roles in the soil environment. Edited by J.B. Dixon and S.B. Weeds. Soil Science Society of America, Madison, WI. p. 741.

Schnitzer, M., and Monreal, C.M. 2011. Quo vadis soil organic matter research? A biological link to the chemistry of humification. Adv. Agron. 113: 139-213.

Schnitzer, M., and Schulten, H.R. 1992. The analysis of soil organic matter by pyrolysis-field ionization mass spectrometry. Soil Sci. Soc. Am. J. 56: 1811-1817. doi:10.2136/sssaj1992 $.03615995005600060027 x$.

Schulten, H.-R. 1984. Relevance of analytical pyrolysis studies to biomass conversion. J. Anal. Appl. Pyrol. 12: 149-187. doi:10 .1016/0165-2370(87)85063-5.

Schulten, H.-R., Monreal, C.M., and Schnitzer, M. 1995. Effect of lon-term cultivation on the chemical structure of soil organic matter. Naturwissenschaften. 82: 42-44.

Sorge, C., Schnitzer, M., and Schulten, H.-R. 1993. In-source pyrolysis-field ionization mass spectrometry and Curie-point pyrolysis-gas chromatography/mass spectrometry ofamino acids in humic substances and soils. Biol. Fertil. Soil. 16: 100-110. doi:10.1007/BF00369410.

Sposito, G. 1984. The surface chemistry of soils.Oxford University Press, New York.

Taboada-Castro, M.M., Alves, M.C., Nascimento, V., and Taboada-Castro, M.T. 2009. Revegetation on a removed topsoil: effect on aggregate stability. Comm. Soil Sci. Plant Anal. 40: 771-786. doi:10.1080/00103620802686916. 
Tyurin, I.V. 1953. Methods of analysis for the comparative study of soil humus composition. Chem. Abstr. 47: 5597.

Universidad de Huelva - UH. 2011. Servicios centrales de investigación. (S.1.:s.n., 200. Available from http://www.uhu.es/ scid/uni_rayosx.html [accessed 30 January 2011].

van Raij, B., Andrade, J.C., Cantarella, H., and Quaggio, J.A. 2001. Análise química para avaliação da fertilidade de solos tropicais. IAC, Campinas, Brasil. 285 p.

van Veen, J.A., and Paul, E.A. 1981. Organic C dynamics in grassland soils. 1: background information and computer simulations. Can. J. Soil Sci. 61: 185-201. doi:10.4141/ cjss81-024.

Wendling, B., Jucksch, I., de Sá Mendoça, E., de Almeida, R.F., Martins, C.E., and da Silva Domingues, L.A. 2014. Simulation of use and management effects on the soil organic matter pools of the Atlantic Forest biome, Brazil. Biosci. J. Uberl. 30: $1278-1290$.

Zinn, Y.L., Lal, R., and Resck, D.V.S. 2005. Changes in soil organic carbon stocks under agriculture in Brazil. Soil Tillage Res. 84: 28-40. doi:10.1016/j.still.2004.08.007. 